\title{
Employees' perceptions of diversity management practices as predictors of psychological capital: A South African study
}

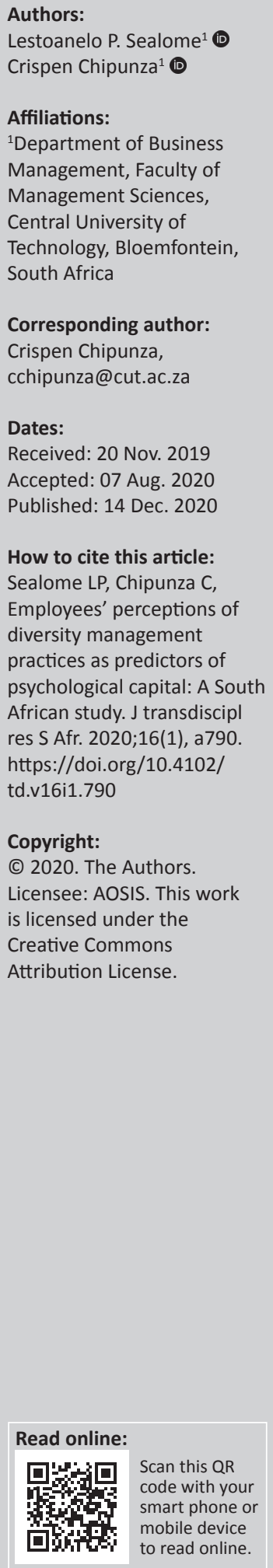

Authors:

Affiliations:

${ }^{1}$ Department of Business Management, Faculty of Central University of Technology, Bloemfontein, South Africa

Crispen Chipunza,

Accepted: 07 Aug. 2020

How to cite this article: Sealome LP, Chipunza C diversity management practices as predictors of psychological capital: A South res S Afr. 2020:16(1) a790. https://doi.org/10.4102/

pyright:

Licensee: AOSIS. This work

is licensed under the

Creative Commons

Attribution License.

mobile device to read online.
Human resource practitioners have recently been interested, especially within large corporations, in diversity management and psychological capital (commonly known as positive psychology) - making the insights from such studies inadequate and difficult to apply in other contexts such as the small business sector. With no known empirical research on these two areas of interest within small businesses, the purpose of this study was to determine the impact of perceptions of diversity management practices on psychological capital amongst employees in bed and breakfast (B\&B) establishments. A quantitative design, specifically a cross-sectional case study design, was adopted. Data were collected from a sample of 144 B\&B employees conveniently selected. The collected data were analysed using both descriptive and inferential statistics. The findings of the study showed that there is a significant and positive relationship between perceived diversity management practices and psychological capital of employees. Specifically, perceived diversity management practices in specific human resource management practices were found to influence the psychological capital of the B\&Bs employees. Given the nature of B\&B establishments, in terms of attracting diverse customers, the study recommends the need of $B \& B$ managers to implement appropriate and fair human resource diversity management practices in order to promote the development of psychological capital amongst employees. This study is the first of its kind to contribute to the literature on diversity management practices and psychological capital within B\&B establishments in a developing context.

Keywords: employees' perceptions; diversity management practices; psychological capital; bed and breakfast establishments.

\section{Introduction}

Hospitality industry is one of the fastest growing sectors in South Africa, offering a wide range of accommodation and attracting a mix of both business and holiday travellers. ${ }^{1,2}$ The industry has a well-documented and significant socio-economic impact in South Africa where it constitutes up to $67 \%$ of all tourism and generates about R179 billion of economic activity, more than 40000 jobs through direct employment representing $7.6 \%$ of total employment in the country. ${ }^{3}$ In concurrence, statistics released by Statistics South Africa ${ }^{4}$ indicated that the largest share of employment in 2017 was in 'hotels, motels and inns', namely, 70\% and this was followed by 'other accommodation' and 'guest-houses and guest-farms', accounting for 22\% and $8 \%$, respectively. Furthermore, Makumbirofa ${ }^{5}$ indicated that these establishments absorb labour and generally expand economies in creative and innovative ways. Despite this evidence and the fact that this industry is structurally dominated by large and well-established enterprises, the contribution of small accommodation businesses in the sector, such as the bed and breakfast (B\&B) establishments, has not been given much empirical attention in many aspects and, therefore, cannot be ignored if their broad range of contributions to different economies is to be understood. ${ }^{6}$

A B\&B is a commercial accommodation establishment that is operated from a private house that is managed by a resident owner or resident lessee and provides sleeping accommodation and breakfast primarily to the tourists or a business market clientele, with the facilities and services being offered for the exclusive use and benefit of overnight registered guests. ${ }^{7}$ The B\&B establishments contribute approximately $9 \%$ of the gross domestic product (GDP) to the annual tourism industry contributions in South Africa. ${ }^{8}$ These establishments recorded the highest yearon-year growth rates in income, with guest-houses and guest-farms recording $24.9 \%$ and B\&Bs at $24.3 \%$, thus showing a significant contribution to the growth of South Africa. ${ }^{9,10}$ 
Despite such contributions to the South African economic growth, these establishments face numerous challenges that inhibit their growth. ${ }^{11}$ One of the major challenges faced by B\&Bs is:

\begin{abstract}
... their inability to compete on the open markets because of poor practices in areas such as diversity management, yet they are organisations that are visited by diverse guests, and naturally, one would expect that diversity management is central to their daily operations (p. 201). ${ }^{12}$
\end{abstract}

According to Ali et al., diversity management is about fundamentally and comprehensively changing the procedures and ways of thinking by focusing on new abilities, skills, attributes and experiences, without prejudice. ${ }^{13}$ Managing diversity is an ongoing process that requires various talents and capabilities found in an organisation. ${ }^{14}$ However, most of the available literature ${ }^{15,16}$ on diversity management within the hospitality sector focuses more on large establishments, leaving small ones such as B\&Bs with no available literature relating to how they are dealing with diversity management issues.

$\mathrm{Ng}$ et al. argued that if diversity management is applied correctly in any organisation, small or large in any sector, several outcomes such as enhanced employees' psychological capital (PsyCap) can be realised. ${ }^{17}$ Psychological capital is explained as 'an employee's positive psychological state of development, characterised by the states of hope, optimism, resilience and self-efficacy ${ }^{\prime} .{ }^{18}$ De Hoe et al. ${ }^{19}$ argued for the enhancement of employees' positive PsyCap as it can play a moderating role in the relationship between the negative results of failure and positive side of learning from these failures. Whilst evidence of the relationship between diversity management practices and PsyCap can be traced in some large hospitality establishments, ${ }^{18}$ there is still a dearth of empirical evidence showing the same in the context of employees in smaller hospitality establishments such as B\&Bs.

\section{Research purpose and objectives}

The aim of this research is to promote the management of diversity in small hospitality businesses such as B\&Bs and demonstrating how it can be used to enhance employees' PsyCap. The reason for this is that B\&Bs in South Africa, in addition to continuing facing challenges such as funding and lack of markets, also suffer from a lack of proper human capital management. ${ }^{20}$ Chipunza ${ }^{21}$ has previously mentioned that most small accommodation businesses in South Africa are by nature diverse and deal with diverse customers, yet not much is known about the management of diversity and positive psychological states of the employees in these entities. Other researchers have highlighted that these two phenomena are critical for the survival of small business establishments in any unpredictable business environment. ${ }^{22}$ Based on the above evidence, the significance of this research study lies within its potential to identify diversity management practices that might be needed by small accommodation businesses in South Africa for these businesses' growth and continued survival. The study will also offer new insights regarding the validity and reliability of scales adopted and developed to measure these two constructs within B\&Bs in a developing context. It is also envisaged that the results of the study might assist the South African government to formulate policies that will extend its current support to the development of employees within small accommodation firms such as B\&Bs.

The main research objective of this study was, therefore, to determine the impact of employees' perceptions of diversity management practices on PsyCap in B\&B establishments in one of the districts in the Free State province of South Africa. The specific research objectives for the study are as follows:

- to determine employees' knowledge and understanding of diversity

- to identify the specific human resource management practices where employees perceive diversity management to be applied by management

- to measure the status of PsyCap of employees amongst the $\mathrm{B} \& \mathrm{~B}$ establishments

- to measure the extent to which employees' perceptions of diversity management practices correlate with their PsyCap.

The research hypotheses for the study are as follows:

H1: Employees have knowledge and understanding of diversity.

H2: There are specific human resource management practices where employees perceive that diversity management is being applied by management.

H3: Employees' psychological capital is positive.

H4: There is a positive correlation between perceived diversity management practices in specific human resource management practices and the psychological capital of employees.

\section{Literature review}

\section{Hospitality industry: A South African perspective}

The hospitality industry has emerged as one of the key economic drivers in South Africa and also as one of the growing industries in the world. ${ }^{23}$ This industry consists of the accommodation sector, which is structurally dominated by well-established enterprises led by the Sun International, Protea and Southern Sun enterprises ${ }^{3}$ and Rogerson, with the vast majority being small enterprises such as B\&Bs (with fewer than 30 rooms and not more than R5 100000 annual turnover. ${ }^{24}$

The small accommodation B\&B sector market in South Africa enjoyed its third consecutive year of strong growth with a $9.1 \%$ advance following 2 years of double-digit gains in $2018 .{ }^{25}$ This growth is, however, rattled with numerous challenges, such as excessive competition because of the increasing number of contemporary accommodation providers (Airbnbs) and the expansion of existing hotels in South Africa that are putting much pressure on the profit margins of $B \& B$ establishments. ${ }^{26}$ 


\section{Bed and breakfast establishments in context}

The number of B\&B establishments has increased dramatically in South Africa as well as throughout the world, in the last 3 years, although there are no exact statistics that show the extent of their growth. ${ }^{27}$ Contrary to this observation, however, there is an argument that B\&B establishments in South Africa are moving very slowly as compared with larger establishments. ${ }^{28}$ The slow growth is attributed to the inability of $\mathrm{B} \& \mathrm{Bs}$ to respond to changing diverse consumer demands (brought in with the advent of Airbnbs) and the operational challenges posed by sophisticated technology. ${ }^{29}$

In fact, research has shown that most of the B\&B establishments in developing countries, such as South Africa, are facing more than these two challenges. ${ }^{30}$ Other challenges such as a lack of government support; the existence of strict regulations; unstable political systems, poor infrastructure and recruitment practices; lack of financial stability; and recently COVID-19 tend to divert $\mathrm{B} \& \mathrm{~B}$ owners from attending to diversity management issues and human resource well-being. ${ }^{21,31}$

Recent studies have emphasised the importance of qualified, skilled and motivated human resources for the hospitality industry to perform well and sustain growth. ${ }^{32}$ Cognisant of the nature of work done by human resources in B\&Bs, such as working long hours and the poor remunerations associated with the industry, a study in Malaysia found the absence of concern for human resource issues amongst many of the small hospitality establishments in the country. ${ }^{33}$ As a result, there were issues of mistrust between employees and employers. Similarly, in India, a recent study found lack of interest in human resource management issues such as provision of training and diversity management. ${ }^{34}$

Literature on human resource management points out that there is a strong correlation between human resources management and development of positive employee states. ${ }^{35}$ Because diversity management is an aspect of human resource management, it is possible to argue that a lack of attention to it has the potential of affecting employees' development of positive states such as hope, self-efficacy, resilience and optimism.

\section{Definition of diversity}

The term 'diversity' has various interpretations. ${ }^{36}$ For the purpose of this study, the definition by Bedi et al. ${ }^{37}$ who viewed diversity as 'policies and practices that seek to include people from within a workforce who are considered to be different from those in the prevailing constituency' is considered. In addition, some authors classify diversity as a broad range of human uniqueness, such as perception and attitudes, work style, lifestyle, personality, values, work ethics, communication style, world view, recreational and personal habits, educational background, work experience, appearance, parental status, marital status and functional levels of classification. ${ }^{38}$ Within the workplace context, diversity, therefore, involves the presence of the different unique aspects of individuals within an organisation ${ }^{39}$ The acknowledgement of such presents can best be practised by adopting correct diversity management practices.

\section{Diversity management practices: A human resource perspective}

The reality that workforce diversity arises from the existence of different employees within the organisation suggests that amongst an organisation's human resource functions, there should be diversity management practices. ${ }^{40}$ Diversity management practices involve activities that encourage employees to value differences in an organisation..$^{41}$ In this regard, it is possible to suggest that the application of diversity management in the workplace involves diversity decisions made in relation to some of the following human resource functional areas.

\section{Recruitment and selection}

Recruitment and selection are two vital human resource management activities that can be considered and included in an organisation's human resource plan. ${ }^{42}$ These activities involve the process of attracting a supply of qualified and diverse applicants for employment ${ }^{41}$. To capitalise on diversity, organisations always try to ensure that recruitment and selection processes are not tainted by stereotyping and discrimination, thus enabling organisations to choose the best talented employee for the job, regardless of their origin. ${ }^{43,44}$ Whilst this is the ideal, Nyarko ${ }^{45}$ highlighted that the majority of small-to-medium enterprise (SME) owners and managers sometimes consider formal recruitment processes as a waste of time because their priority is profitmaking - creating the potential for discrimination to arise. To avoid such poor approaches, several recommendations have been suggested that can be used to improve the management of workforce diversity in recruitment. ${ }^{45}$ These include (1) the development of a job description and selection process that covers job-relevant duties, qualifications and experiences and complies with anti-discrimination legislation; (2) advertisements in ethnic language press in addition to daily newspapers, and use of a variety of recruiters, including international ones; (3) diverse multinationals in the human resource departments, making them participate in the selection and hiring processes; and (4) applying specific interviewing techniques when dealing with culturally diverse applicants.

\section{Training and development}

Diversity training refers to organisational effort that seeks to inform and educate employees about the promotion of favourable attitudes and adoption of skills and behaviour that promote diversity. ${ }^{46}$ This means that the provision of training and development opportunities should be commensurate with eliminating group or race differences in career outcomes and generate respect for individual differences, attitudes, values and behaviour. ${ }^{44}$ When group or race differences is eliminated in training and development, 
researchers argue that this approach creates greater sensitivity to the challenges presented in the management of diversity. ${ }^{47}$ Similarly, other researchers advocate for approaches to diversity management in training and development that deal with cultural sensitivity, stereotyping and other inaccurate perceptions on diversity when working in a multicultural environment. ${ }^{48}$

Despite these suggestions, recent research has shown that managers and owners of small-to-medium enterprises in the hospitality sector (including B\&B establishments) ignore the training and development of employees. They consider it a costly exercise, suggesting the need for practitioners and researchers to proffer empirical evidence on the need, not only to consider training and development of employees, but also to do it in a way that engenders the application of diversity management approaches. ${ }^{49}$ It is thus possible to suggest that when B\&Bs adopt diversity training and development, especially amongst employees from diverse social groups, this demonstrates tolerance for individual differences, which might result in the improvement of both individual and organisational performance. Indeed, previous studies have demonstrated the correlation between application of diversity in training and development, employee performance and organisational success. ${ }^{50,51}$

\section{Performance appraisal}

Performance appraisal in the context of the study would mean understanding that a more diverse and inclusive work environment can yield greater productivity and help improve individual as well as organisational performance. Researchers suggest that to improve the effectiveness of performance appraisal practices in diversity, strategies such as involving minorities in panels during the evaluation process and ensuring that the appraisal process focuses on evaluating the individual's performance and not on personality are encouraged. ${ }^{52}$ Padachi et al. ${ }^{47}$ concurred and further suggested that encouraging diversity by including multicultural employees on panels who evaluate and emphasising the cultural neutrality of the appraisal process is seen as an important aspect of diversity management. Although performance appraisal systems are not common in small businesses such as B\&Bs because of their size, there is evidence from research conducted on small accommodation businesses in Kenya that owner-managers preferred working with or promoting employees not only based on ethnic groups but also through performance appraisals - indicating embracing diversity of employees' performance within their organisations. ${ }^{53,54}$

\section{Reward and compensation}

Compensation is a crucial segment of human resource management that requires planning, organising and controlling a variety of payment systems used to reward employees who perform jobs or services..$^{55}$ Compensation ensures that there is a direct relationship between employee efforts and reward. ${ }^{56}$ Within the context of diversity management, this aspect means that equal pay for equal jobs within the workplaces and avoiding unexplained differences amongst employees should be promoted. Empirical evidence to support this assertion is from a case study of a small businesses in South Australia that had policies on equal pay for equal work, which were supported by the employees who all held the view that remuneration was equitable, based on performance and not influenced by any other factors. ${ }^{57}$ Consistent with this, previous researchers ${ }^{47}$ argue that employees should be given a voice in the development of reward policies and practices and the right to explanations on decisions and how they would have been arrived at as part of managing diversity in reward and compensation.

Idow $\mathrm{u}^{52}$ outlined approaches that can be utilised to improve diversity management and these include (1) reducing wage disparities by using an equal and fair distribution of rewards between employees regardless of origin and (2) making the different nationalities feel recognised and appreciated. The implementation of these diversity management practices, from a human resource perspective, allows integration and eradicates negative elements that affect diversity and productivity and rather work towards increased productivity. Furthermore, managing diversity in this way has been found to allow the taping into underutilised skills within an organisation through the removal of existing diversity stereotyping that would have overlooked such skills. ${ }^{58}$ This argument is reiterated by authors who argue that the application of diversity management in reward and compensation has ramifications for the development of positive attitudes, commitment and motivation amongst employees. ${ }^{59}$ What this entails within the context of the present study is that B\&B owner-managers who consider diversity management whilst recognising employees' performance and contribution regardless of their origin are likely to promote the development of psychological states, such as self-efficacy, optimism, hope and resilience.

\section{Diversity management practices in bed and breakfast establishments}

For the purpose of this study, B\&B establishments are conceptualised as SMEs. Unlike large enterprises that are usually passionate about diversifying their workforce and view it as a norm and continuously strive to improve diversity management, $\mathrm{B} \& \mathrm{~B}$ establishments have a unique perspective about the role of diversity and the features of diversity practices that respond to their needs. ${ }^{60}$ These establishments perceive diversity management as a choice and only inevitable when they feel it is a burden or they can effectively manage it. ${ }^{61}$

To support these facts, a previous study noted that $B \& B$ establishments often lack time, means and expertise to implement efficient and integrated diversity practices and usually fear to commit because they deem diversity management practices as too onerous as they are logistically and strategically demanding. ${ }^{62}$ However, Chiu ${ }^{63}$ indicated that B\&B establishments could develop diversity management practices that are suitable for their own requirements. 
Several studies, although not necessarily in B\&Bs, are significant to testify the need for them to develop their own diversity management practices. For example, Chiu's ${ }^{63}$ study identified a small business in Taiwan that took a relatively informal diversity management practice by using community networks and word of mouth to attract and recruit multicultural employees who appreciated the opportunity. This strategy indicated the value of application of diversity management in the workplace. In addition, other studies identified that small businesses in Spain that designed and set up a profile aimed at attracting and retaining talent regardless of individual differences and based on a work-related criterion grounded on merit and not discrimination. ${ }^{62}$ This means that it is possible for $B \& B$ establishments to take a more individualised approach to diversity management by recruiting and retaining employees who have been exposed to a variety of people, ideas and perspectives and have different educational, prior business experiences and personal networks.

Few examples can also be noted as to how some small businesses applied diversity management practices in their human resource functions. For example, one study found that employees in small businesses in the United States of America were evaluated by their managers. ${ }^{64}$ In South Australia, another study found that with respect to training and development, there were mixed opinions towards the importance of diversity training perceptions by small businesses. ${ }^{65}$ The authors contended that although diversity training was regarded as essential, the majority of small businesses in the study did not provide any diversity training for employees from dominant cultures and from multicultural backgrounds. However, in other parts of the country, previous studies had indicated that the presence of a diverse workforce witnessed employees from small businesses being sent for diversity and language training to build a strong bond between employees. ${ }^{66}$

It is clear from the above studies that there is no uniformity in the implementation of diversity management practices within small businesses (including B\&B establishments). In addition, the above-mentioned studies seem to have been conducted in developing economies and one could argue that contextual differences may provide different scenarios all together, influenced by factors such as the nature of the business, the beliefs and values of the Chief Executive Officer (CEO) and the size of the business. ${ }^{67}$

\section{Psychological capital}

According to researchers, psychological capital (PsyCap) has the integrative common thread running through the four dimensions (self-efficacy, optimism, hope and resilience) of a motivational propensity to accomplish goals and succeed.$^{68}$ It is not positioned as simply a summation of its individual components, but rather as a higher-order core construct that integrates the four psychological resources. As such, PsyCap is theorised as having more impact on performance and other desirable outcomes than on the individual psychological resources that comprise it. ${ }^{69}$
Psychological capital is a positive state-like capacity that has been empirically developed through theory building and research. ${ }^{70}$ It is a resource that goes beyond human capital (experience, knowledge, skills and abilities) and social capital (relationships, networks). ${ }^{70}$ The concept of PsyCap and each construct included in it may have stability over time, but they are expected not to be as stable as personality traits and other evaluations and are, therefore, state-like and open to change and development. ${ }^{71}$ In line with the context of the study, PsyCap is defined as an employee's positive psychological state of development. ${ }^{72}$

Research has investigated several aspects within the organisations that are positively influenced by the PsyCap. For instance, a recent research has analysed the effect of PsyCap on employee turnover and established that although problems such as salary scales, low promotion rate, working days and service experience have caused high employee turnover, employee turnover can be reduced if PsyCap is positively developed. ${ }^{73}$ Previous studies that analysed PsyCap in the relationship between the independent work environment and self-directed behaviours have indicated that employees who perceive the work environment in their organisations as more independent are likely to experience higher levels of PsyCap, which in turn impact positively their self-directed behaviour. ${ }^{74}$

Similarly, several researchers have also shown a link between employees' PsyCap and the level of work engagement, ${ }^{75,76,77}$ employee job satisfaction, employee well-being and feelings of gainful employment, ${ }^{76}$ increased employee competencies and organisational citizenship behaviour. ${ }^{78}$ Within the $B \& B$ context, a recent invetsigation ${ }^{79}$ found it as a powerful positive resource with the ability to enhance B\&B employees' productivity and achieve business growth.

\section{Psychological capital dimensions}

Four positive psychological dimensions found to be measurable, open to developing and related to work performance and desirable outcomes are self-efficacy, hope, optimism and resilience. ${ }^{80}$

\section{Self-efficacy}

Self-efficacy is a human resource strength that has the psychological capacity for development and effective performance management. ${ }^{75}$ It is linked with individuals' convictions about their own capacity in carrying out a set of actions that successfully lead to a desired outcome..$^{80}$ Thus, when individuals have a high self-efficacy, they are willing to take on challenging tasks, extend their motivation and effort in order to achieve goals successfully and to persist in the face of adversity. ${ }^{69}$ In addition, individuals with high self-efficacy do not wait for goals to be set for them - they create their own discrepancies by continuously challenging themselves and setting higher goals. ${ }^{75}$

\section{Hope}

Hope is the process of thinking about one's goals along the motivation to move towards those goals (agency) and the 
ways to achieve those (pathways) ${ }^{80}$ Individuals are motivated to achieve goals through their sense of agency, which fosters internal determination and willpower to invest the energy necessary for achieving the desired goals, with more hopeful individuals being more motivated by the desire to develop ways to get things that they want. ${ }^{69}$ This in turn allows them to generate multiple pathways to continuously envision goal attainment and success as they prepared to create alternative routes in the case of an obstacle blocking the current path. ${ }^{81}$

\section{Optimism}

Optimism is a general expectation for future good outcomes and optimistic individuals expect to experience good things, whereas pessimistic individuals expect bad things in life. ${ }^{80}$ Optimists expect positive and desirable events in the future and tend to attribute their success to themselves and global attributes, whereas failures are attributed to external attributes specific to the situation. ${ }^{75}$ Nonetheless, optimism may also have dysfunctions in the workplace as employees who are physically healthy may be optimistic about their health in the future and neglect their physical and nutritional maintenance at the present time. ${ }^{76}$ In order to address these dysfunctions that could ordinarily result in a cost for the organisation, one needs to construct a realistic optimism, which involves an objective assessment of what an individual can accomplish within a specific context and takes the available time and resources into consideration. ${ }^{75}$

\section{Resilience}

Resilience refers to having the capacity to bounce back from adversity, failure or even to seem overwhelmingly positive. ${ }^{82}$ It is a process of good adaption under extenuating circumstances that enables individuals to rapidly overcome or rejuvenate after a setback or failure. ${ }^{80}$ Resilience allows for both reactive recovery and proactive learning and growth through conquering challenges. ${ }^{83}$ In addition, resilient people move on in life after having had a stressful experience or event such as personal adversity, conflict and/or failure. ${ }^{84}$

It is important to note that there is interaction between the above PsyCap dimensions. For example, a person who is trustful might be able to use hope, optimism and resilience for specific tasks in different areas of his or her life. A resilient person might use coping mechanisms to develop a realistic and flexible optimism. In turn, self-efficacy, hope and resilience can also help a person in the development of a positive attribution style to act under one's control. ${ }^{85}$ Therefore, B\&B establishments might have to invest in training programmes that are designed for developing and building these psychological dimensions. In that way, these dimensions could assist to understand the psychological strengths within each employee, which in turn might result in improved competitiveness through investment in human capital.

\section{Psychological capital in the hospitality industry}

Few recorded studies have indicated that developing PsyCap in employees may serve as an important catalyst to improve performance within the hospitality industry. For example, one study showed that hospitality interns' positive PsyCap was significantly associated with their performance. ${ }^{86}$ Similarly, another study indicated that hospitality industry employees who had a high positive PsyCap of 'self-efficacy' were able to overcome problems because they had confidence to fix the problem by themselves and they had the 'hope' that they would get better in the future but only after facing the problems. ${ }^{77}$ The only challenge with these studies was that they used samples from large hospitality firms.

\section{Diversity management and psychological capital}

Despite the growing literature on both diversity management and PsyCap, no empirical evidence exists on the relationship between the two variables in the context of developing economies, specifically B\&B establishments. Although not directly within the hospitality sector per se, available literature argues that embracing diversity and managing it can increase one's willingness to remain in an organisation and improve human capital skills that are inimitable. ${ }^{87}$ With such effect of diversity management, it can be argued that directing the reflectiveness, adaptiveness and responsiveness of employees to a workplace environment where diversity is well managed can have the potential for the improvement of their PsyCap attributes. This assumption is supported by researchers who underscore the importance of resiliencebuilding programmes in the workplace as a means of equipping individuals with the resources and skills necessary to function effectively. ${ }^{88}$ Such resilience-building programmes can incorporate elements of diversity management for the improvement of the psychological functioning of employees and their general well-being. ${ }^{89}$

A number of other studies focusing mainly on positive organisational behaviour identified cross-cultural leadership as part of diversity management and PsyCap and argued that organisations constantly need employees and leadership who can effectively work across a diverse workforce (diversity receptivity) and succeed..$^{90,91}$ Other studies supported this finding when they illustrated that cross-cultural leadership directly impacts the self-efficacy of employees. ${ }^{92}$ The fusion of self-efficacy and managing diversity properly helps in the decisions that employees make when they are tasked to deal with diverse situations and resolve problems emanating from the diverse nature of colleagues. For example, one study confirmed that a well-managed age-diversity assists younger employees to improve their self-efficacy when dealing with older employees within the organisation. ${ }^{88}$

From the few given examples, one can conclude that managing diversity influences employees' attitudes, behaviour and PsyCap. This justifies the relationship between diversity management and the PsyCap of employees, an area worth for further investigation, in different contexts; hence, 
in line with the context of this study, the adoption of appropriate diversity management practices by the owners and/or managers of $B \& B$ establishments is assumed to impact positively the PsyCap of their employees.

\section{Theoretical framework}

This study was guided by the PERMA model. This is a positive psychology theory, which was introduced by the positive psychologist Martin Seligman in 2011. ${ }^{93}$ PERMA stands for the five essential elements that should be in place for people to experience lasting well-being, namely, positive emotions, engagement, relationships, meaning and accomplishment. ${ }^{94}$ Underlying this theory is the assumption that an increase in the PERMA elements can lead to improved mental health, creativity, relationships and work performance. ${ }^{95}$ In line with the context of this study, it is expected that if owners or managers of B\&B establishments apply and enhance diversity management in human resource functions, employees' well-being in the form of emotions, work relationships, engagement and meaning will improve. The presence of these elements triggers positive PsyCap dimensions such as hope, optimism, selfefficacy and resiliency, which have been found to be essential for the growth and survival of a firm. ${ }^{96}$

\section{Research design}

This study adopted a quantitative design, specifically the cross-sectional case study design, where a case of B\&B's establishments in one of the districts in the Free State province of South Africa was conveniently identified.

\section{Research method}

The target population of the study comprised employees working in B\&Bs situated in one of the districts in the Free State province of South Africa. At the onset of this study, there were $77 \mathrm{~B} \& \mathrm{Bs}$, with each employing an average of three people. Thus, the total population of the study was approximately 231 employees. The sample size calculator recommends a sample size of 144 for this population size, at a confidence interval of $95 \%$. Although 144 questionnaires were distributed, only 100 were returned and usable, thus representing a response rate of $69 \%$. The study sample included 100 employees employed in the participating B\&Bs.

The final sample consisted of $71 \%$ men and $29 \%$ women. The most common age group was $21-30$ years (39\%) and 31-40 years $(35 \%)$. In terms of the population group, $51 \%$ were black people, followed by $34 \%$ white people, $14 \%$ mixed-race people and $1 \%$ Indians. Most of the respondents spoke Sesotho (48\%) and Africans (42\%) and were mainly Christians (93\%). Most of the respondents were heterosexual (89\%). As far as educational qualification is concerned, $37 \%$ of the participants had achieved Grade 12, followed by 35\% who had attained diplomas and degrees, whilst 19\% did not have any formal qualification.

\section{Measuring instrument}

The measuring instrument was a questionnaire consisting of four sections. Section A comprised nine questions that required respondents to detail their demographical and biographical information, such as gender, age, ethnicity, languages spoken, religion, sexual orientation, qualifications, job levels and years in service at the B\&Bs.

Section B was on how employees value diversity. This was performed by soliciting their knowledge and understanding of diversity. An example of an item in this section was 'diversity in the workplace is the different unique aspects of individuals'. Section C focused on the respondents' perceptions of diversity management practices utilised at their B\&Bs, focusing on recruitment and selection, training and development, performance appraisal and reward as well as compensation. An example of an item in this section is 'our organisation creates an organisational climate that attracts diverse individuals from the labour market'. Section D focused on the respondents' PsyCap status. An example of an item in this section is 'I feel confident helping to set targets or goals in my work area'. Sections B-D items were measured on a six-point Likert scale format, ranging from (1) strongly disagree to (6) strongly agree.

\section{Research procedure}

The questionnaire was personally distributed by the researcher. During this stage, the researcher allowed the $\mathrm{B} \& \mathrm{Bs}$ to stipulate dates for the collection of completed questionnaires. The researcher, as the person who knew what the expected data should look like, reviewed the questionnaires as they were handed back to ensure that all appropriate fields were completed. It was also an opportunity for the researcher to extend the gratitude to the $\mathrm{B} \& \mathrm{Bs}^{\prime}$ employers for their participation.

\section{Ethical consideration}

The Faculty of Management Sciences Research Ethics Committee at the Central University of Technology, Free State granted the necessary ethical clearance (PCD/2019), in August 2019. Permission to carry out the study was sought from the owners of the B\&Bs. Participants were requested to sign letters of consent to ensure that voluntary participation was adhered to. In addition, the questionnaire's introduction section assured the participants of the confidentiality, anonymity, respect for privacy and protection of their dignity; hence, they were not requested to identify themselves when completing the questionnaire.

\section{Statistical analysis}

Data were cleaned and analysed using the Statistical Package for Social Science (SPSS) Version 25. Descriptive statistics were used to report the sample responses to all questions using frequencies, measures of central tendencies (mean) and that of variation (standard deviation). Inferential statistics, such as exploratory factor analysis, 
Cronbach's alpha coefficient, Kolmogorov-Smirnov (K-S) test, Shapiro-Wilk test and the Pearson correlations, were used to answer the research questions by testing the hypothesised relationships between the key variables (diversity management and PsyCap).

\section{Results}

\section{Validity and reliability of the questionnaire}

The study ensured face validity by effectively covering the constructs of diversity management practices and PsyCap from the literature review. In addition, the questionnaire received input from experts in diversity management as well as from a statistician to ensure correct wording and the use of appropriate scales of measurement. The reliability of the instrument was measured by Cronbach's alpha coefficient. The reliability results are presented in Table 1.

TABLE 1: Scale reliability statistics.

\begin{tabular}{|c|c|c|c|}
\hline Construct & $\begin{array}{l}\text { Number } \\
\text { of items }\end{array}$ & $\begin{array}{l}\text { Cronbach's } \\
\text { alpha }\end{array}$ & Comment \\
\hline \multicolumn{4}{|c|}{ Knowledge and understanding of diversity } \\
\hline Uniqueness and interaction & 3 & 0.783 & - \\
\hline $\begin{array}{l}\text { Ethnic, gender and individual } \\
\text { tolerance for progress }\end{array}$ & 5 & 0.857 & High internal consistency \\
\hline \multicolumn{4}{|c|}{ Diversity in organisation's management practices } \\
\hline \multicolumn{4}{|c|}{ Diversity in recruitment and selection } \\
\hline $\begin{array}{l}\text { Employee attraction and } \\
\text { retention }\end{array}$ & 2 & 0.697 & $\begin{array}{l}\text { Moderate internal } \\
\text { consistency }\end{array}$ \\
\hline Employee selection methods & 3 & 0.756 & - \\
\hline Training and development & 5 & 0.942 & High internal consistency \\
\hline Performance appraisal & 5 & 0.861 & High internal consistency \\
\hline Reward and compensation & 4 & 0.916 & High internal consistency \\
\hline \multicolumn{4}{|l|}{ Psychological capital } \\
\hline Hope & 4 & 0.835 & High internal consistency \\
\hline Efficacy & 4 & 0.928 & High internal consistency \\
\hline Resilience & 3 & 0.873 & High internal consistency \\
\hline Optimism & 3 & 0.833 & High internal consistency \\
\hline Overall questionnaire & 41 & 0.952 & High internal consistency \\
\hline All Likert scaled questions & - & - & - \\
\hline
\end{tabular}

Note: The whole questionnaire was considered highly reliable with a Cronbach's alpha coefficient of 0.952 .

TABLE 2: Exploratory factor analysis of the sub-construct of knowledge and understanding of diversity.

\begin{tabular}{lcc}
\hline $\begin{array}{l}\text { Sub-constructs of knowledge and } \\
\text { understanding of diversity }\end{array}$ & \multicolumn{1}{c}{ Principal components (latent factors) } \\
\cline { 2 - 3 } $\begin{array}{l}\text { Q10. I have knowledge and } \\
\text { understanding of diversity }\end{array}$ & $\mathbf{1}$ & $\mathbf{2}$ \\
$\begin{array}{l}\text { Q11. Diversity is an unique aspect of } \\
\text { individuals }\end{array}$ & 0.656 & - \\
$\begin{array}{l}\text { Q12. Diversity represents interactions } \\
\text { from different backgrounds }\end{array}$ & 0.901 & - \\
$\begin{array}{l}\text { Q13. Understanding organisation's } \\
\text { case for diversity }\end{array}$ & - & - \\
$\begin{array}{l}\text { Q14. Comfortable initiating diversity } \\
\text { issues with colleagues }\end{array}$ & - & 0.745 \\
$\begin{array}{l}\text { Q15. Diversity is about ethnicity and } \\
\text { gender }\end{array}$ & - & 0.830 \\
$\begin{array}{l}\text { Q16. Diversity ensures sustainable } \\
\text { future for company }\end{array}$ & - & 0.698 \\
$\begin{array}{l}\text { Q17. Diversity is tolerance of } \\
\text { individual differences }\end{array}$ & - & 0.802 \\
$\begin{array}{l}\text { Cronbach's alpha } \\
\text { Suggested sub-construct name }\end{array}$ & $\begin{array}{c}\text { Uniqueness } \\
\text { and interaction }\end{array}$ & $\begin{array}{c}\text { Ethnic, gender and } \\
\text { individual tolerance } \\
\text { for progress }\end{array}$ \\
\hline
\end{tabular}

\section{Exploratory factor analysis}

Exploratory factor was employed to determine the different dimensions measured by the questionnaire. Exploratory factor analysis (EFA) is used when a researcher wants to discover the number of factors influencing variables and to analyse which variables or items go together. ${ }^{98}$ The results are presented here.

\section{Exploratory factor analysis of knowledge and understanding of diversity}

Exploratory factor analysis based on principal components was carried out on the eight items of knowledge and understanding of diversity and two sub-constructs were obtained as shown in Table 2. Questions 10-12 formed a sub-construct with the suggested name 'uniqueness and interaction', whereas questions 13-17 formed another subconstruct with the suggested names 'ethnic, gender and individual tolerance for progress'. These sub-construct names were based on the nature of the questions that fall under them.

The knowledge and understanding of diversity sub-construct of uniqueness and interaction is made up of three questionnaire items as presented in Table 3. The results indicate that $86 \%$ of the participants agree or strongly agree that they knew the meaning of diversity. Most of the participants $(78 \%)$ view diversity in the workplace as a unique aspect of individuals, whilst $86 \%$ agree or strongly agree that diversity manifests itself when people of different backgrounds interact.

The knowledge and understanding of diversity sub-construct of ethnic, gender and individual tolerance for progress has five items as shown in Table 4 . The results indicate that $73 \%$ of the participants understand their organisations' issues on diversity. From the data it can be noted that $75 \%$ of the participants agree or strongly agree that they are comfortable in initiating diversity issues with their colleagues; $71 \%$ agree or strongly agree that diversity is primarily about ethnicity and gender issues. Most of the participants (79\%) agree or strongly agree that diversity has an important role in ensuring a sustainable future for their companies and 79\% also agree or strongly agree that diversity is about tolerance of individual differences.

\section{Exploratory factor analysis of organisational diversity in recruitment and selection}

Exploratory factor analysis based on principal components was carried out on the five items of organisational diversity in recruitment and selection and two sub-constructs were obtained as shown in Table 5. Questions 18 and 19 formed a sub-construct with the suggested name 'Employee Attraction and Retention', while questions 20-22 formed another subconstruct with the suggested name 'Employee Selection Methods'.

The results in Table 6 indicate that most of the participants (69\%) agree or strongly agree that their organisations 
TABLE 3: Analysis of the sub-construct of uniqueness and interaction.

\begin{tabular}{|c|c|c|c|c|c|c|c|c|c|}
\hline \multirow[t]{2}{*}{ Diversity: Uniqueness and interaction } & \multicolumn{6}{|c|}{ Frequency distribution } & \multicolumn{2}{|c|}{ Descriptive } & \multirow{2}{*}{$\begin{array}{c}\text { Latent factor } \\
\text { (principal } \\
\text { component) } \\
\text { coefficient }\end{array}$} \\
\hline & $\begin{array}{l}\text { Strongly } \\
\text { disagree }\end{array}$ & Disagree & Neutral & Agree & $\begin{array}{l}\text { Strongly } \\
\text { agree }\end{array}$ & $\begin{array}{l}\% \text { Agree or } \\
\text { strongly agree }\end{array}$ & Mean & SD & \\
\hline $\begin{array}{l}\text { 10. I know and understand the meaning } \\
\text { of diversity. }\end{array}$ & - & - & - & - & - & 86.0 & 4.21 & 0.76 & 0.770 \\
\hline Count & 0 & 3 & 11 & 48 & 38 & - & - & - & - \\
\hline$\%$ & 0.0 & 3.0 & 11.0 & 48.0 & 38.0 & - & - & - & - \\
\hline $\begin{array}{l}\text { 11. Diversity in the workplace represents } \\
\text { the different unique aspects of individuals. }\end{array}$ & - & - & - & - & - & 78.0 & 4.09 & 0.87 & 0.853 \\
\hline Count & 1 & 3 & 18 & 42 & 36 & - & - & - & - \\
\hline$\%$ & 1.0 & 3.0 & 18.0 & 42.0 & 36.0 & - & - & - & - \\
\hline $\begin{array}{l}\text { 12. Diversity is interaction of people from } \\
\text { different backgrounds. }\end{array}$ & - & - & - & - & - & 86.0 & 4.3 & 0.7 & 0.888 \\
\hline Count & 0 & 1 & 13 & 45 & 41 & - & - & - & - \\
\hline$\%$ & 0.0 & 1.0 & 13.0 & 45.0 & 41.0 & - & - & - & - \\
\hline
\end{tabular}

Note: Cronbach's alpha $=0.783$

$S D$, standard deviation.

TABLE 4: Analysis of the sub-construct of ethnic, gender and individual tolerance for progress.

\begin{tabular}{|c|c|c|c|c|c|c|c|c|c|}
\hline \multirow{2}{*}{$\begin{array}{l}\text { Diversity: Ethnic, gender and individual } \\
\text { tolerance for progress }\end{array}$} & \multicolumn{6}{|c|}{ Frequency distribution } & \multicolumn{2}{|c|}{ Descriptive } & \multirow{2}{*}{$\begin{array}{c}\text { Latent factor } \\
\text { (principal } \\
\text { component) } \\
\text { coefficient }\end{array}$} \\
\hline & $\begin{array}{l}\text { Strongly } \\
\text { disagree }\end{array}$ & Disagree & Neutral & Agree & $\begin{array}{l}\text { Strongly } \\
\text { agree }\end{array}$ & $\begin{array}{l}\% \text { Agree or } \\
\text { strongly agree }\end{array}$ & Mean & SD & \\
\hline $\begin{array}{l}\text { 13. I understand the organisation's case for } \\
\text { diversity. }\end{array}$ & - & - & - & - & - & 73.0 & 3.92 & 0.92 & 0.756 \\
\hline Count & 1 & 7 & 19 & 45 & 28 & - & - & - & - \\
\hline$\%$ & 1.0 & 7.0 & 19.0 & 45.0 & 28.0 & - & - & - & - \\
\hline $\begin{array}{l}\text { 14. I am comfortable initiating diversity } \\
\text { issues with my colleagues. }\end{array}$ & - & - & - & - & - & 75.0 & 4.01 & 0.92 & 0.818 \\
\hline Count & 0 & 8 & 17 & 41 & 34 & - & - & - & - \\
\hline$\%$ & 0.0 & 8.0 & 17.0 & 41.0 & 34.0 & - & - & - & - \\
\hline $\begin{array}{l}\text { 15. Diversity is primarily about ethnicity } \\
\text { and gender issues. }\end{array}$ & - & - & - & - & - & 71.0 & 3.79 & 1.08 & 0.741 \\
\hline Count & 1 & 18 & 10 & 43 & 28 & - & - & - & - \\
\hline$\%$ & 1.0 & 18.0 & 10.0 & 43.0 & 28.0 & - & - & - & - \\
\hline $\begin{array}{l}\text { 16. Diversity has an important role in ensuring } \\
\text { a sustainable future for our company. }\end{array}$ & - & - & - & - & - & 79.0 & 4.08 & 0.87 & 0.836 \\
\hline$\%$ & 1.0 & 4.0 & 16.0 & 44.0 & 35.0 & - & - & - & - \\
\hline $\begin{array}{l}\text { 17. Diversity is about tolerance of individual } \\
\text { differences. }\end{array}$ & - & - & - & - & - & 79.0 & 4.12 & 0.81 & 0.868 \\
\hline Count & 0 & 3 & 18 & 43 & 36 & - & - & - & - \\
\hline$\%$ & $\%$ & 0. & 3.0 & 18.0 & 43.0 & 36.0 & - & - & - \\
\hline
\end{tabular}

Note: Cronbach's alpha $=0.857$.

$S D$, standard deviation.

TABLE 5: Exploratory factor analysis of organisational diversity in recruitment and selection.

\begin{tabular}{lcc}
\hline $\begin{array}{l}\text { Sub-constructs of organisational } \\
\text { diversity in recruitment and selection }\end{array}$ & \multicolumn{2}{c}{ Principal components (latent factors) } \\
\cline { 2 - 3 } & $\mathbf{1}$ & $\mathbf{2}$ \\
\hline $\begin{array}{l}\text { Q18. Organisation attracts diverse } \\
\text { individuals. }\end{array}$ & 0.830 & - \\
$\begin{array}{l}\text { Q19. Organisation retains employees } \\
\text { from different backgrounds. }\end{array}$ & 0.872 & - \\
$\begin{array}{l}\text { Q20. Specific interview techniques } \\
\text { are applied for diverse applicants. }\end{array}$ & - & 0.849 \\
$\begin{array}{l}\text { Q21. Jobs are advertised in a language } \\
\text { that accommodates diverse candidates. }\end{array}$ & - & 0.871 \\
$\begin{array}{l}\text { Q22. Selection measures are not } \\
\text { potentially unfairly discriminatory. }\end{array}$ & - & 0.604 \\
$\begin{array}{l}\text { Cronbach's alpha } \\
\text { Suggested sub-construct name }\end{array}$ & $\begin{array}{c}\text { Employee attraction } \\
\text { and retention }\end{array}$ & $\begin{array}{c}\text { Employee selection } \\
\text { methods }\end{array}$ \\
\hline
\end{tabular}

create an organisational climate that attracts diverse individuals from the labour market; $75 \%$ indicated that they agree or strongly agree that their organisation retains employees from different backgrounds. These results also indicate that there is a fair amount of consideration of diversity issues in the attraction and retention of employees.

The results in Table 7 indicate that $55 \%$ of participants agree or strongly agree that specific interviewing techniques are applied when dealing with diverse applicants in their organisations, $65 \%$ agree or strongly agree that their organisations advertise jobs in a language that accommodates diverse candidates and $67 \%$ agree or strongly agree that during recruitment their organisations ensure that selection measures are not potentially discriminatory.

\section{Exploratory factor analysis of training and development}

After conducting exploratory factor analysis, it was found that the construct of training and development cannot be split into any sub-constructs. As shown in Table $8,45 \%$ of participants agreed or strongly agreed that training is offered for diverse social groups in their organisation, $29 \%$ 
TABLE 6: Analysis of the sub-construct of employee attraction and retention.

Organisational diversity in recruitment and selection

- Employee attraction and retention

18. Our organisation creates an organisational

climate that attracts diverse individuals from the

labour market.

Count

$\%$

19. My organisation retains employees from different backgrounds.

Count

$\%$

Note: Cronbach's alpha $=0.697$

$S D$, standard deviation.

TABLE 7: Analysis of the sub-construct of employee selection methods.

Organisational diversity in $\quad$ Frequency distribution

recruitment and selection

- Employee selection methods

20. In our organisation, specific interviewing

techniques are applied when dealing with

diverse applicants.

$\begin{array}{llllll}\text { Count } & 5 & 13 & 27 & 44 & 11 \\ \% & 5 & 13 & 27 & 44 & 11\end{array}$

21. Our organisation advertises jobs in

a language to accommodate diverse

candidates.

Count

$\%$

22. During recruitment my organisation

ensures that selection measures are not

\begin{tabular}{|c|c|c|c|c|c|c|c|c|}
\hline \multicolumn{6}{|c|}{ Frequency distribution } & \multicolumn{2}{|c|}{ Descriptive } & \multirow{2}{*}{$\begin{array}{l}\text { Latent factor } \\
\text { (principal } \\
\text { component) } \\
\text { coefficient }\end{array}$} \\
\hline $\begin{array}{l}\text { Strongly } \\
\text { disagree }\end{array}$ & Disagree & Neutral & Agree & $\begin{array}{l}\text { Strongly } \\
\text { agree }\end{array}$ & $\begin{array}{c}\text { \% Agree or } \\
\text { strongly agree }\end{array}$ & Mean & SD & \\
\hline & & & & & 69 & 3.86 & 0.83 & 0.795 \\
\hline
\end{tabular}

potentially unfairly discriminatory.

\begin{tabular}{llllll} 
Count & 3 & 5 & 25 & 44 & 23 \\
$\%$ & 3 & 5 & 25 & 44 & 23 \\
\hline
\end{tabular}

Note: Cronbach's alpha $=0.756$

$S D$, standard deviation.

TABLE 8: Analysis of the construct of training and development.

\begin{tabular}{|c|c|c|c|c|c|c|c|c|c|}
\hline \multirow[t]{2}{*}{ Training and development } & \multicolumn{6}{|c|}{ Frequency distribution } & \multicolumn{2}{|c|}{ Descriptive } & \multirow{2}{*}{$\begin{array}{c}\text { Latent factor } \\
\text { (principal } \\
\text { component) } \\
\text { coefficient }\end{array}$} \\
\hline & $\begin{array}{l}\text { Strongly } \\
\text { disagree }\end{array}$ & Disagree & Neutral & Agree & $\begin{array}{l}\text { Strongly } \\
\text { agree }\end{array}$ & $\begin{array}{l}\text { \% Agree or } \\
\text { strongly agree }\end{array}$ & Mean & SD & \\
\hline $\begin{array}{l}\text { 23. Training is offered for diverse social } \\
\text { groups in my organisation. }\end{array}$ & - & - & - & - & - & 45 & 3.25 & 1.12 & 0.889 \\
\hline Count & 7 & 19 & 29 & 32 & 13 & - & - & - & - \\
\hline$\%$ & 7 & 19 & 29 & 32 & 13 & - & - & - & - \\
\hline $\begin{array}{l}\text { 24. Our organisation promotes employee } \\
\text { participation during diversity training. }\end{array}$ & - & - & - & - & - & 44 & 3.26 & 1.08 & 0.885 \\
\hline Count & 6 & 18 & 32 & 32 & 12 & - & - & - & - \\
\hline$\%$ & 6 & 18 & 32 & 32 & 12 & - & - & - & - \\
\hline $\begin{array}{l}\text { 25. Training offered helps create awareness } \\
\text { on individual differences. }\end{array}$ & - & - & - & - & - & 48 & 3.29 & 1.09 & 0.905 \\
\hline Count & 7 & 16 & 29 & 37 & 11 & - & - & - & - \\
\hline$\%$ & 7 & 16 & 29 & 37 & 11 & - & - & - & - \\
\hline $\begin{array}{l}\text { 26. Training offered provides a platform for } \\
\text { the free and open expression of beliefs. }\end{array}$ & - & - & - & - & - & 57 & 3.45 & 1.07 & 0.921 \\
\hline Count & 4 & 18 & 21 & 43 & 14 & - & - & - & - \\
\hline$\%$ & 4 & 18 & 21 & 43 & 14 & - & - & - & - \\
\hline $\begin{array}{l}\text { 27. Employees are informed about diversity } \\
\text { policies and initiatives during trainings in } \\
\text { our organisation. }\end{array}$ & - & - & - & - & - & 42 & 3.19 & 1.13 & 0.909 \\
\hline Count & 7 & 22 & 29 & 29 & 13 & - & - & - & - \\
\hline$\%$ & 7 & 22 & 29 & 29 & 13 & - & - & - & - \\
\hline
\end{tabular}

Note: Cronbach's alpha $=0.942$

$S D$, standard deviation. 
were neutral, and only $7 \%$ and $19 \%$ strongly disagreed and disagreed, respectively. As indicated in the table, $44 \%$ of the respondents agree or strongly agree that their organisations promote employee participation during diversity training, $48 \%$ agree or strongly agree that training offered by their organisations helps create awareness on individual differences and 57\% agree or strongly agree that the training offered provides a platform for the free and open expression of beliefs. Table 8 also indicates that $42 \%$ of the participants agree or strongly agree with the assertion that employees in their organisations are informed about diversity policies and initiatives during trainings.

\section{Exploratory factor analysis of performance appraisal}

Exploratory factor analysis found that the construct of 'performance appraisal' cannot be split into any subconstructs. The results of the construct are presented in Table 9 . From the data in the table, $46 \%$ of the respondents believed that in their organisations, there are equitable systems for employees despite their individual differences, $34 \%$ were neutral and $17 \%$ disagreed. About $43 \%$ of the respondents agreed or strongly agreed that their organisation involves all diverse stakeholders during the performance evaluation processes, and $37 \%$ were neutral. It is also indicated in the table that $48 \%$ of the participants agreed or strongly agreed that diverse populations are represented in their organisations' staff complement for appraisal processes, and 39\% remained neutral. Furthermore, $47 \%$ of the participants claimed that their performance appraisal techniques focus on appraising employees' performance, not individual differences, whilst $62 \%$ agreed or strongly agreed that employees in their organisations are offered opportunities for promotion, regardless of background or circumstances.

\section{Exploratory factor analysis of reward and compensation}

Exploratory factor analysis showed that the construct of reward and compensation cannot be split into any subconstructs. The results of the construct are presented in Table 10. The table indicates that $58 \%$ of the respondents agree or strongly agree that they feel recognised as employees despite their diversity, 25\% were neutral. More than half of the respondents (56\%) agree or strongly agree that their organisations have fair practices on reward systems despite individual differences, whilst $50 \%$ feel that their organisations provide equal pay for equal job despite individual differences and that their efforts match the rewards granted by their organisations.

\section{Exploratory factor analysis of hope}

The construct of 'hope' could not be split into any subconstructs after exploratory factor analysis. The results of the construct are presented in Table 11. The table indicates that $85 \%$ of the respondents somewhat agree or agree or strongly agree that they see themselves as being successful at work, $8 \%$ somewhat disagree, $2 \%$ disagree and 5\% strongly disagree. It can also be inferred from the table that $91 \%$ of the respondents somewhat agree or agree or strongly agree that they can think of a way to get out of a jam should they find themselves in one at work, $6 \%$ somewhat disagree, $1 \%$ disagree and $2 \%$ strongly disagree. Most of the respondents (79\%) somewhat agree or agree or strongly agree that they think of many ways to reach their current work goals and 91\% somewhat agree or agree or strongly agree and believe that there are many ways around any problem.

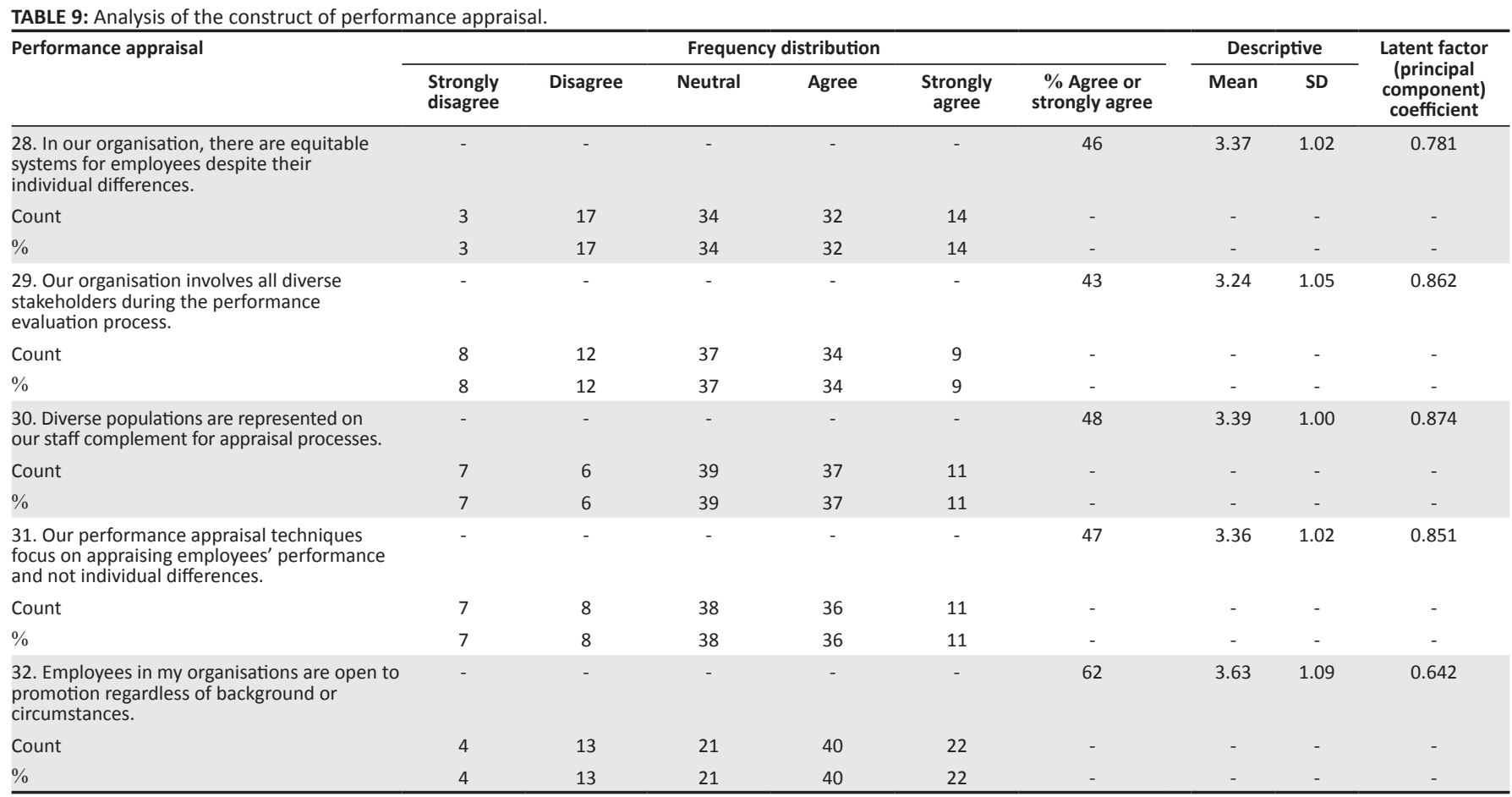

Note: Cronbach's alpha $=0.861$

$S D$, standard deviation. 
TABLE 10: Analysis of the construct of reward and compensation.

\begin{tabular}{|c|c|c|c|c|c|c|c|c|c|}
\hline \multirow[t]{2}{*}{ Reward and compensation } & \multicolumn{6}{|c|}{ Frequency distribution } & \multicolumn{2}{|c|}{ Descriptive } & \multirow{2}{*}{$\begin{array}{c}\text { Latent factor } \\
\text { (principal } \\
\text { component) } \\
\text { coefficient }\end{array}$} \\
\hline & $\begin{array}{l}\text { Strongly } \\
\text { disagree }\end{array}$ & Disagree & Neutral & Agree & $\begin{array}{l}\text { Strongly } \\
\text { agree }\end{array}$ & $\begin{array}{l}\text { \% Agree or } \\
\text { strongly agree }\end{array}$ & Mean & SD & \\
\hline $\begin{array}{l}\text { 33. We all feel recognised as employees } \\
\text { despite our diversity. }\end{array}$ & - & - & - & - & - & 58 & 3.64 & 1.13 & 0.851 \\
\hline Count & 4 & 13 & 25 & 31 & 27 & - & - & - & - \\
\hline$\%$ & 4 & 13 & 25 & 31 & 27 & & & & \\
\hline $\begin{array}{l}\text { 34. There is a fair practice on reward systems } \\
\text { despite individual differences. }\end{array}$ & - & - & - & - & - & 56 & 3.52 & 1.10 & 0.936 \\
\hline Count & 5 & 13 & 26 & 37 & 19 & - & - & - & - \\
\hline$\%$ & 5 & 13 & 26 & 37 & 19 & & & & \\
\hline $\begin{array}{l}\text { 35. Our organisation provides equal pay for } \\
\text { equal jobs despite our individual differences. }\end{array}$ & - & - & - & - & - & 50 & 3.38 & 1.22 & 0.897 \\
\hline Count & 12 & 7 & 31 & 31 & 19 & - & - & - & - \\
\hline$\%$ & 12 & 7 & 31 & 31 & 19 & - & - & - & - \\
\hline $\begin{array}{l}36 . \text { Our efforts match the rewards granted } \\
\text { by our organisation. }\end{array}$ & - & - & - & - & - & 50 & 3.35 & 1.27 & 0.896 \\
\hline$\%$ & 12 & 12 & 26 & 29 & 21 & - & - & - & - \\
\hline
\end{tabular}

Note: Cronbach's alpha $=0.916$

$S D$, standard deviation.

TABLE 11: Analysis of the construct of hope.

\begin{tabular}{|c|c|c|c|c|c|c|c|c|c|c|}
\hline \multirow[t]{2}{*}{ Hope } & \multicolumn{7}{|c|}{ Frequency distribution } & \multicolumn{2}{|c|}{ Descriptive } & \multirow{2}{*}{$\begin{array}{c}\text { Latent factor } \\
\text { (principal } \\
\text { component) } \\
\text { coefficient }\end{array}$} \\
\hline & $\begin{array}{l}\text { Strongly } \\
\text { disagree }\end{array}$ & Disagree & $\begin{array}{l}\text { Somewhat } \\
\text { disagree }\end{array}$ & $\begin{array}{l}\text { Somewhat } \\
\text { agree }\end{array}$ & Agree & $\begin{array}{l}\text { Strongly } \\
\text { agree }\end{array}$ & $\begin{array}{c}\% \text { Somewhat } \\
\text { agree or agree } \\
\text { or strongly } \\
\text { agree }\end{array}$ & Mean & SD & \\
\hline $\begin{array}{l}\text { 37. Right now I see myself as being pretty } \\
\text { successful at work. }\end{array}$ & - & - & - & - & - & - & 85 & 4.63 & 1.32 & 0.749 \\
\hline Count & 5 & 2 & 8 & 25 & 30 & 30 & - & - & - & - \\
\hline$\%$ & 5 & 2 & 8 & 25 & 30 & 30 & - & - & - & - \\
\hline Count & 2 & 1 & 6 & 12 & 42 & 37 & - & - & - & - \\
\hline$\%$ & 2 & 1 & 6 & 12 & 42 & 37 & - & - & - & - \\
\hline $\begin{array}{l}\text { 39. I can think of many ways to reach my } \\
\text { current work goals. }\end{array}$ & - & - & - & - & - & - & 79 & 5.09 & 1.08 & 0.899 \\
\hline Count & 5 & 4 & 12 & 35 & 44 & & - & - & - & - \\
\hline$\%$ & 5 & 4 & 12 & 35 & 44 & 0 & - & - & - & - \\
\hline $\begin{array}{l}\text { 40. There are a number of ways around } \\
\text { any problem. }\end{array}$ & - & - & - & - & - & - & 91 & 5.09 & 1.14 & 0.841 \\
\hline Count & 1 & 5 & 3 & 11 & 35 & 45 & - & - & - & - \\
\hline$\%$ & 1 & 5 & 3 & 11 & 35 & 45 & - & - & - & - \\
\hline
\end{tabular}

Note: Cronbach's alpha $=0.835$.

$S D$, standard deviation.

\section{Exploratory factor analysis of efficacy}

Similarly, after conducting an exploratory factor analysis, it was found that the construct of efficacy cannot be split into any sub-constructs. Table 12 presents the results of the questionnaire items on efficacy. The data indicate that most of the participants (92\%) feel confident in analysing a longterm problem to find a solution and $98 \%$ also feel confident in representing their work area in meetings with management. Most of the respondents (92\%) feel confident in helping to set targets or goals in their work area, whilst $89 \%$ somewhat agree or agree or strongly agree that they feel confident in presenting information to a group of colleagues.

\section{Exploratory factor analysis of resilience}

The construct of resilience could also not be split into any sub-constructs. Table 13, which represents the results of the questionnaire items on resilience, shows that $92 \%$ of the participants somewhat agree or agree or strongly agree that they usually manage difficulties in one way or another at work, whilst $90 \%$ claimed that they can recover from setbacks at work. Most of the participants (91\%) also stated that they feel that they can handle many things simultaneously in their job.

\section{Exploratory factor analysis of optimism}

After conducting an exploratory factor analysis, it was found that the construct of optimism cannot be split into any subconstructs. Table 14 shows that $92 \%$ of the respondents somewhat agree or agree or strongly agree that they always look on the bright side of things regarding their jobs. The majority (92\%) of respondents indicated that they approach their jobs as if every cloud has a silver lining, and 91\% were optimistic about what will happen to them in the future as it pertains to work. 
TABLE 12: Analysis of the construct of efficacy.

\begin{tabular}{|c|c|c|c|c|c|c|c|c|c|c|}
\hline \multirow[t]{2}{*}{ Efficacy } & \multicolumn{7}{|c|}{ Frequency distribution } & \multicolumn{2}{|c|}{ Descriptive } & \multirow{2}{*}{$\begin{array}{l}\text { Latent factor } \\
\text { (principal } \\
\text { component) } \\
\text { coefficient }\end{array}$} \\
\hline & $\begin{array}{l}\text { Strongly } \\
\text { disagree }\end{array}$ & Disagree & $\begin{array}{l}\text { Somewhat } \\
\text { disagree }\end{array}$ & $\begin{array}{l}\text { Somewhat } \\
\text { agree }\end{array}$ & Agree & $\begin{array}{l}\text { Strongly } \\
\text { agree }\end{array}$ & $\begin{array}{l}\text { \% Somewhat } \\
\text { agree or agree } \\
\text { or strongly } \\
\text { agree }\end{array}$ & Mean & SD & \\
\hline $\begin{array}{l}\text { 41. I feel confident in analysing a } \\
\text { long-term problem to find a solution. }\end{array}$ & - & - & - & - & - & - & 92 & 5.12 & 1.16 & 0.811 \\
\hline Count & 2 & 4 & 2 & 11 & 34 & 47 & - & - & - & - \\
\hline$\%$ & 2 & 4 & 2 & 11 & 34 & 47 & - & - & - & - \\
\hline $\begin{array}{l}\text { 42. I feel confident in representing my } \\
\text { work area in meetings with management. }\end{array}$ & - & - & - & - & - & - & 89 & 5.06 & 1.24 & 0.960 \\
\hline Count & 2 & 5 & 4 & 11 & 30 & 48 & - & - & - & - \\
\hline$\%$ & 2 & 5 & 4 & 11 & 30 & 48 & - & - & - & - \\
\hline $\begin{array}{l}\text { 43. I feel confident in helping to set } \\
\text { targets/goals in my work area. }\end{array}$ & - & - & - & - & - & - & 92 & 5.05 & 1.20 & 0.907 \\
\hline Count & 3 & 4 & 1 & 12 & 37 & 43 & - & - & - & - \\
\hline$\%$ & 3 & 4 & 1 & 12 & 37 & 43 & - & - & - & - \\
\hline Count & 2 & 5 & 4 & 8 & 32 & 49 & - & - & - & - \\
\hline$\%$ & 2 & 5 & 4 & 8 & 32 & 49 & - & - & - & - \\
\hline
\end{tabular}

Note: Cronbach's alpha $=0.928$

$S D$, standard deviation.

TABLE 13: Analysis of the construct of resilience.

\begin{tabular}{|c|c|c|c|c|c|c|c|c|c|c|}
\hline \multirow[t]{2}{*}{ Resilience } & \multicolumn{7}{|c|}{ Frequency distribution } & \multicolumn{2}{|c|}{ Descriptive } & \multirow{2}{*}{$\begin{array}{c}\text { Latent factor } \\
\text { (principal } \\
\text { component) } \\
\text { coefficient }\end{array}$} \\
\hline & $\begin{array}{l}\text { Strongly } \\
\text { disagree }\end{array}$ & Disagree & $\begin{array}{l}\text { Somewhat } \\
\text { disagree }\end{array}$ & $\begin{array}{l}\text { Somewhat } \\
\text { agree }\end{array}$ & Agree & $\begin{array}{l}\text { Strongly } \\
\text { agree }\end{array}$ & $\begin{array}{c}\text { \% Somewhat } \\
\text { agree or agree } \\
\text { or strongly } \\
\text { agree }\end{array}$ & Mean & SD & \\
\hline $\begin{array}{l}\text { 45. I usually manage difficulties one } \\
\text { way or another at work. }\end{array}$ & - & - & - & - & - & - & 92 & 5.12 & 1.04 & 0.832 \\
\hline Count & 1 & 2 & 5 & 11 & 38 & 43 & - & - & - & - \\
\hline$\%$ & 1 & 2 & 5 & 11 & 38 & 43 & - & - & - & - \\
\hline $\begin{array}{l}\text { 46. When I have a setback at work, } \\
\text { I manage to recover from it, moving on. }\end{array}$ & - & - & - & - & - & - & 90 & 5.07 & 1.17 & 0.915 \\
\hline Count & 2 & 4 & 4 & 8 & 39 & 43 & - & - & - & - \\
\hline$\%$ & 2 & 4 & 4 & 8 & 39 & 43 & - & - & - & - \\
\hline $\begin{array}{l}\text { 47. I feel I can handle many things } \\
\text { at a time at this job. }\end{array}$ & - & - & - & - & - & - & 91 & 5.13 & 1.17 & 0.928 \\
\hline Count & 3 & 2 & 4 & 8 & 36 & 47 & - & - & - & - \\
\hline$\%$ & 3 & 2 & 4 & 8 & 36 & 47 & - & - & - & - \\
\hline
\end{tabular}

Note: Cronbach's alpha $=0.873$.

$S D$, standard deviation.

TABLE 14: Analysis of the construct of optimism.

\begin{tabular}{|c|c|c|c|c|c|c|c|c|c|c|}
\hline \multirow[t]{2}{*}{ Optimism } & \multicolumn{7}{|c|}{ Frequency distribution } & \multicolumn{2}{|c|}{ Descriptive } & \multirow{2}{*}{$\begin{array}{l}\text { Latent factor } \\
\text { (principal } \\
\text { component) } \\
\text { coefficient }\end{array}$} \\
\hline & $\begin{array}{l}\text { Strongly } \\
\text { disagree }\end{array}$ & Disagree & $\begin{array}{l}\text { Somewhat } \\
\text { disagree }\end{array}$ & $\begin{array}{l}\text { Somewhat } \\
\text { agree }\end{array}$ & Agree & $\begin{array}{l}\text { Strongly } \\
\text { agree }\end{array}$ & $\begin{array}{l}\text { \% Somewhat } \\
\text { agree or agree } \\
\text { or strongly } \\
\text { agree }\end{array}$ & Mean & SD & \\
\hline $\begin{array}{l}48.1 \text { always look on the bright side of } \\
\text { things regarding my job. }\end{array}$ & - & - & - & - & - & - & 92 & 5.15 & 1.13 & 0.874 \\
\hline Count & 2 & 2 & 4 & 13 & 29 & 50 & - & - & - & - \\
\hline$\%$ & 2 & 2 & 4 & 13 & 29 & 50 & - & - & - & - \\
\hline $\begin{array}{l}49.1 \text { approach this job as if every cloud has } \\
\text { a silver lining. }\end{array}$ & - & - & - & - & - & - & 92 & 5.21 & 1.13 & 0.915 \\
\hline Count & 2 & 3 & 3 & 8 & 32 & 52 & - & - & - & - \\
\hline$\%$ & 2 & 3 & 3 & 8 & 32 & 52 & - & - & - & - \\
\hline $\begin{array}{l}50 . \text { I am optimistic about what will happen } \\
\text { to me in the future as it pertains to work. }\end{array}$ & - & - & - & - & - & - & 91 & 5.00 & 1.23 & 0.814 \\
\hline Count & 2 & 5 & 2 & 19 & 26 & 46 & - & - & - & - \\
\hline$\%$ & 2 & 5 & 2 & 19 & 26 & 46 & - & - & - & - \\
\hline
\end{tabular}

Note: Cronbach's alpha $=0.833$.

$S D$, standard deviation. 


\section{Test of normality}

In this study, a normality test was performed using the K-S test and the Shapiro-Wilk test. Kolmogorov-Smirnov test is an empirical distribution function (EDF) in which the theoretical cumulative distribution function of the test distribution is contrasted with the EDF of the data. ${ }^{97}$ The Shapiro-Wilk test is defined as one of the most popular tests for normality distribution diagnostics, which has good properties of power and is based on correlation within given observations and associated normal scores. ${ }^{98}$

The four constructs of PsyCap were measured on a sixpoint Likert scale. The overall means of each of the four PsyCap are presented in Table 15. The results show that, in general, optimism has the highest score (mean $=5.120$ ), followed by resilience $($ mean $=5.107)$, efficacy $($ mean $=$ 5.083) and, lastly, hope (mean $=4.958$ ). The PsyCap variables were constructed by finding the means of the questionnaire items that fall under them. The measurement of overall PsyCap was obtained by averaging all the questionnaire items that fell under the four constructs that are listed in Table 15.

Psychological capital variables are dependent variables that are affected by diversity management practices; therefore, it was important to check the normality of these variables to decide whether parametric or nonparametric tests can be used. The normality tests are presented in Table 16. The results show that all four constructs of PsyCap and their overall measure are not normally distributed as all the $p$-values of the K-S and the Shapiro-Wilk tests are all less than 0.05 , which indicate that there is significant departure from normality on all four variables and their overall measure.

As the response variables are not normal, it was not possible to carry out regression analysis or analysis of variance because these methods are based on the assumption of

TABLE 15: Summary statistics of the four constructs of psychological capital.

\begin{tabular}{lccccc}
\hline $\begin{array}{l}\text { Descriptive statistics for } \\
\text { psychological capital }\end{array}$ & $\boldsymbol{N}$ & Minimum & Maximum & Mean & SD \\
\hline Hope & 100 & 1.50 & 6.00 & 4.958 & 0.946 \\
Efficacy & 100 & 1.00 & 6.00 & 5.083 & 1.094 \\
Resilience & 100 & 1.33 & 6.00 & 5.107 & 1.005 \\
Optimism & 100 & 1.00 & 6.00 & 5.120 & 1.009 \\
$\begin{array}{l}\text { Overall psychological capital } \\
\text { of employees }\end{array}$ & 100 & 1.21 & 6.00 & 5.060 & 0.918 \\
\hline
\end{tabular}

$S D$, standard deviation.

TABLE 16: Test of normality of psychological capital variables.

\begin{tabular}{|c|c|c|c|c|c|c|}
\hline \multirow[t]{2}{*}{ Variable } & \multicolumn{3}{|c|}{ Kolmogorov-Smirnov $\dagger$} & \multicolumn{3}{|c|}{ Shapiro-Wilk } \\
\hline & Statistic & $d f$ & $p$ & Statistic & $d f$ & $p$ \\
\hline Hope & 0.183 & 100 & 0.000 & 0.864 & 100 & 0.000 \\
\hline Efficacy & 0.230 & 100 & 0.000 & 0.797 & 100 & 0.000 \\
\hline Resilience & 0.218 & 100 & 0.000 & 0.804 & 100 & 0.000 \\
\hline Optimism & 0.192 & 100 & 0.000 & 0.815 & 100 & 0.000 \\
\hline $\begin{array}{l}\text { Overall psychological } \\
\text { capital of employees }\end{array}$ & 0.153 & 100 & 0.000 & 0.850 & 100 & 0.000 \\
\hline
\end{tabular}

$\dagger$, Lilliefors significance correction. normality. The relationship between PsyCap variables as dependent variables and diversity management practices as independent variables was assessed by means of correlation analysis.

\section{Correlation analysis of knowledge and understanding of diversity and psychological capital of employees}

The Pearson correlation was used to test the hypothesised relationships of the key variables (diversity management and PsyCap).

Results in Table 17 show that whilst PsyCap variables are highly correlated amongst themselves (correlations $\geq 0.645$ ), their correlations with 'knowledge and understanding of diversity' variables are rather low, although most of them are significant, and thus the 'knowledge and understanding of diversity' variable has low effect size on PsyCap. Furthermore, the results show that the PsyCap variable of resilience is not correlated with the 'knowledge and understanding of diversity' variable of ethnic, gender and individual tolerance for progress (correlation $=0.186, p=0.065$ ). In terms of effect size, ranges of correlations between knowledge and understanding of diversity against all PsyCap variables have a wider range (more effect) for ethnic, gender and individual tolerance for progress $(0.150$ to 0.350$)$ than for uniqueness and interaction (0.251 to 0.259$)$.

\section{Correlation analysis of specific human resource management practices where employees perceive diversity to be applied by management and psychological capital of employees}

Results in Table 18 show that the diversity management practice variable of employee attraction and retention is significantly correlated to all PsyCap variables (all $p$-values $<0.05$ ). Hope is not significantly correlated to employee selection methods (correlation $=0.151, p=0.133$ ) and training and development (correlation $=0.171, p=0.089$ ) but significantly correlated to the other three diversity management practices variables ( $p$-values $<0.05$ ): employee attraction and retention, performance appraisal, and rewards and compensation. In addition, the results show that the diversity management practices variable with the least effect on PsyCap is training and development, which had the smallest correlation values with diversity management practice variables $(0.167 \leq$ correlation $\leq 0.242)$. Furthermore, the results also show that the diversity management practices variable with the least effect on PsyCap is training and development, which had the smallest correlation values with diversity management practice variables $(0.167 \leq$ correlation $\leq 0.242)$. In terms of effect size, ranges of correlations between diversity management practices against all PsyCap variables have a wider range (more effect) for employee selection methods (0.100 to $0.302)$ and reward and compensation (0.302 to 0.405) than for all other practices. 
TABLE 17: Correlations of knowledge and understanding of diversity and psychological capital variables.

\begin{tabular}{|c|c|c|c|c|c|c|}
\hline \multirow[t]{2}{*}{ Pearson correlations } & \multicolumn{2}{|c|}{ Knowledge and understanding of diversity } & \multicolumn{4}{|c|}{ Psychological capital } \\
\hline & $\begin{array}{l}\text { Uniqueness and } \\
\text { interaction }\end{array}$ & $\begin{array}{l}\text { Ethnic, gender and individual } \\
\text { tolerance for progress }\end{array}$ & Hope & Efficacy & Resilience & Optimism \\
\hline \multicolumn{7}{|l|}{ Knowledge and understanding of diversity } \\
\hline Uniqueness and interaction & - & - & - & - & - & - \\
\hline Correlation & - & - & - & - & - & - \\
\hline$p$ & - & - & - & - & - & - \\
\hline$N$ & - & - & - & - & - & - \\
\hline Ethnic, gender and individual tolerance for progress & - & - & - & - & - & - \\
\hline Correlation & $0.532^{* *}$ & - & - & - & - & - \\
\hline$p$ & 0.000 & - & - & - & - & - \\
\hline$N$ & 100 & - & - & - & - & - \\
\hline \multicolumn{7}{|l|}{ Psychological capital } \\
\hline Hope & - & - & - & - & - & - \\
\hline Correlation & $0.302^{* *}$ & $0.352^{* *}$ & - & - & - & - \\
\hline$N$ & 100 & 100 & - & - & - & - \\
\hline Efficacy & - & - & - & - & - & - \\
\hline Correlation & $0.277^{* *}$ & $0.256^{*}$ & $0.739^{* * *}$ & - & - & - \\
\hline$p$ & 0.005 & 0.010 & 0.000 & - & - & - \\
\hline$N$ & 100 & 100 & 100 & - & - & - \\
\hline Resilience & - & - & - & - & - & - \\
\hline Correlation & $0.270^{* * *}$ & 0.186 & $0.645^{* * *}$ & $0.883^{* * *}$ & - & - \\
\hline$p$ & 0.007 & 0.065 & 0.000 & 0.000 & - & - \\
\hline$N$ & 100 & 100 & 100 & 100 & - & - \\
\hline Optimism & - & - & - & - & - & - \\
\hline Correlation & $0.316^{* *}$ & $0.362^{* *}$ & $0.799^{* * *}$ & $0.726^{* *}$ & $0.730^{* *}$ & - \\
\hline$p$ & 0.001 & 0.000 & 0.000 & 0.000 & 0.000 & - \\
\hline$N$ & 100 & 100 & 100 & 100 & 100 & - \\
\hline Overall psychological capital of employees & - & - & - & - & - & - \\
\hline$N$ & 100 & 100 & 100 & 100 & 100 & 100 \\
\hline
\end{tabular}

*, Correlation is significant at the 0.05 level (2-tailed); **, Correlation is significant at the 0.01 level (2-tailed).

\section{Discussion}

\section{Knowledge and understanding of diversity}

In terms of uniqueness and interaction as the first subconstruct of knowledge and understanding of diversity, the results show that respondents regard diversity as a unique set of individuals and they tolerate it. The results support the argument of Treuren et al. ${ }^{99}$ who indicated that because of the nature of hospitality industry, diversity is an essential factor that managers and employees should understand. Failure to fully understand the complexity of diversity may influence the effectiveness of diversity programmes or initiatives. ${ }^{100}$ Other findings also note that organisations that understand and value individual differences and learn how to effectively manage a diverse workforce reap the benefits for their success. ${ }^{101}$

Regarding ethnic, gender and individual tolerance for progress as the second sub-construct of knowledge and understanding of diversity, the results showed that diversity is well understood as essential for organisational sustainability and tolerance of individual differences is understood as a pillar for the organisation. These results are reaffirmed by Daniels ${ }^{100}$ who stated that although organisations are faced with challenges in understanding differences and instituting effective diversity management initiatives, managing diversity is an approach for creating an environment in which employees become aware of it and regard it as part of the ingredients for organisational success. Similarly, a recent study indicated that the more hospitality organisations evaluate and utilise their diversity policies and plan for the future, the more employees embrace them, and the more profit and value the organisation might gain. ${ }^{102}$ Despite these revelations, however, organisations in the hospitality industry still encounter difficulties in effectively managing cultural differences. ${ }^{40}$

\section{Diversity management practices}

The results of the sub-construct of employee attraction and retention under recruitment showed that the B\&Bs attract diverse workforce. These results are in tandem with the findings that organisations such as B\&B establishments are built around individuals who incorporate their diverse backgrounds, insights and experience to remain competitive. ${ }^{103}$ In support, recent studies have pointed out that hospitality organisations by the nature of their strategic position employ people from different cultures, countries and regions; therefore, improving fairness and equal employment 
TABLE 18: Correlations of diversity management practices and psychological capital variables.

\begin{tabular}{|c|c|c|c|c|c|c|c|c|c|}
\hline \multirow[t]{2}{*}{ Pearson correlations } & \multicolumn{5}{|c|}{ Diversity management practices } & \multicolumn{4}{|c|}{ Psychological capital } \\
\hline & $\begin{array}{l}\text { Employee } \\
\text { attraction and } \\
\text { retention }\end{array}$ & $\begin{array}{l}\text { Employee } \\
\text { selection } \\
\text { methods }\end{array}$ & $\begin{array}{l}\text { Training and } \\
\text { development }\end{array}$ & $\begin{array}{l}\text { Performance } \\
\text { appraisal }\end{array}$ & $\begin{array}{l}\text { Reward and } \\
\text { compensation }\end{array}$ & Hope & Efficacy & Resilience & Optimism \\
\hline Employee attraction and retention & - & - & - & - & - & - & - & - & - \\
\hline Correlation & - & - & - & - & - & - & - & - & - \\
\hline$p$ & - & - & - & - & - & - & - & - & - \\
\hline Employee selection methods & - & - & - & - & - & - & - & - & - \\
\hline Correlation & $0.420^{* *}$ & - & - & - & - & - & - & - & - \\
\hline$p$ & 0.000 & - & - & - & - & - & - & - & - \\
\hline$N$ & 100 & - & - & - & - & - & - & - & - \\
\hline Training and development & - & - & - & - & - & - & - & - & - \\
\hline Correlation & $0.497^{* *}$ & $0.507^{* *}$ & - & - & - & - & - & - & - \\
\hline$p$ & 0.000 & 0.000 & - & - & - & - & - & - & - \\
\hline Performance appraisal & - & - & - & - & - & - & - & - & - \\
\hline Correlation & $0.587^{* *}$ & $0.555^{* *}$ & $0.677^{* *}$ & - & - & - & - & - & - \\
\hline$p$ & 0.000 & 0.000 & 0.000 & - & - & - & - & - & - \\
\hline$N$ & 100 & 100 & 100 & - & - & - & - & - & - \\
\hline Reward and compensation & - & - & - & - & - & - & - & - & - \\
\hline Correlation & $0.506^{* *}$ & $0.414^{* *}$ & $0.510^{* *}$ & $0.693^{* * *}$ & - & - & - & - & - \\
\hline$p$ & 0.000 & 0.000 & 0.000 & 0.000 & - & - & - & - & - \\
\hline$N$ & 100 & 100 & 100 & 100 & - & - & - & - & - \\
\hline \multicolumn{10}{|l|}{ Psychological capital } \\
\hline Hope & - & - & - & - & - & - & - & - & - \\
\hline Correlation & $0.332^{* *}$ & 0.151 & 0.171 & $0.325^{* *}$ & $0.482^{* *}$ & - & - & - & - \\
\hline$p$ & 0.001 & 0.133 & 0.089 & 0.001 & 0.000 & - & - & - & - \\
\hline$N$ & 100 & 100 & 100 & 100 & 100 & - & - & - & - \\
\hline Efficacy & - & - & - & - & - & - & - & - & - \\
\hline$p$ & 0.000 & 0.001 & 0.030 & 0.000 & 0.000 & 0.000 & - & - & - \\
\hline$N$ & 100 & 100 & 100 & 100 & 100 & 100 & - & - & - \\
\hline Resilience & - & - & - & - & - & - & - & - & - \\
\hline Correlation & $0.368^{* *}$ & $0.307^{* *}$ & $0.242^{*}$ & $0.391^{* * *}$ & $0.351^{* *}$ & $0.645^{* *}$ & $0.883^{* *}$ & - & - \\
\hline$p$ & 0.000 & 0.002 & 0.015 & 0.000 & 0.000 & 0.000 & 0.000 & - & - \\
\hline$N$ & 100 & 100 & 100 & 100 & 100 & 100 & 100 & - & - \\
\hline Optimism & - & - & - & - & - & - & - & - & - \\
\hline Correlation & $0.358^{* *}$ & $0.219^{*}$ & 0.167 & $0.319^{* * *}$ & $0.367^{* *}$ & $0.799^{* *}$ & $0.726^{* *}$ & $0.730^{* * *}$ & - \\
\hline$p$ & 0.000 & 0.029 & 0.096 & 0.001 & 0.000 & 0.000 & 0.000 & 0.000 & - \\
\hline$N$ & 100 & 100 & 100 & 100 & 100 & 100 & 100 & 100 & - \\
\hline Overall psychological capital of employees & - & - & - & - & - & - & - & - & - \\
\hline Correlation & $0.400^{* *}$ & $0.281^{* *}$ & $0.220^{*}$ & $0.397^{* *}$ & $0.468^{* *}$ & $0.886^{* *}$ & $0.937^{* *}$ & $0.897^{* *}$ & $0.889^{* *}$ \\
\hline$p$ & 0.000 & 0.005 & 0.028 & 0.000 & 0.000 & 0.000 & 0.000 & 0.000 & 0.000 \\
\hline$N$ & 100 & 100 & 100 & 100 & 100 & 100 & 100 & 100 & 100 \\
\hline
\end{tabular}

*, Correlation is significant at the 0.05 level (2-tailed); **, Correlation is significant at the 0.01 level (2-tailed).

opportunities is vital. ${ }^{40,104}$ These results also support the notion that, to capitalise on diversity, organisations need to ensure that recruitment and selection processes are not tainted by stereotyping and discriminations. ${ }^{43}$

On the contrary, other researchers argue that although many organisations seek to hire people of diverse backgrounds to increase the quality of decision-making and creativity, some strong cultures often seek to minimise diversity, thus missing out on the benefits derived from having a diverse workforce. ${ }^{105}$ Singh et al. also claimed that some SMEs owners and managers consider formal recruitment processes a waste of time and that their priority is to make high production and profit, thus creating the potential for discrimination to arise. ${ }^{106}$

With regard to the sub-construct of employee selection methods under recruitment, the results indicate that B\&Bs are not discriminatory in their selection and recruitment activities. Selection criteria are viewed as a diversity management technique that also serves as a preventative measure to meet the challenge of a diverse workforce to prepare and select candidates with required attributes. ${ }^{107}$ However, some studies ${ }^{108}$ have indicated that SMEs 
(including B\&B establishments) are confronted with issues such as legislative requirements of equal employment opportunity and anti-discrimination when doing their recruitment and selection to the extent that they cannot evade recruiting and selecting from diverse contexts. The current results are also supported by a study indicating that to improve the management of workforce diversity in recruitment and selection, there should be a development of selection processes such as advertising for jobs in ethnic languages and the use of diversified hiring processes when dealing with culturally diverse candidates. ${ }^{109}$

In terms of training and development, the results reveal that $\mathrm{B} \& \mathrm{~B}$ establishments offer diversity training to their employees. To retain the already-hired diverse employees, studies have indicated that management should provide adequate training and development opportunities that can help eliminate group differences in career outcomes and generate respect for individual differences. ${ }^{110}$ In concurrence, Kalargyrou et al. emphasised the urgency of hospitality organisations in creating and conducting effective diversity training for their employees to increase their awareness. ${ }^{40}$ Similar studies have advocated that diversity training is especially necessary in hospitality and other service segments because restaurants and hotels employ women and minorities in great numbers. ${ }^{111}$ Other recent research findings, however, contradict these results by indicating that owners-managers of $\mathrm{B} \& \mathrm{~B}$ establishments ignore the training and development of employees as they consider it a costly exercise. ${ }^{112}$

In relation to the results on performance appraisal that indicated the activity is positively viewed in B\&Bs, previous studies have found that there are various steps that an organisation can consider for improving its performance appraisal systems and practices within the diversity component. These include, amongst others, having diverse individuals as part of the panel discussions whilst evaluating, selecting and promoting. ${ }^{113}$ In support of this argument, Idowu $\mathrm{u}^{52}$ outlined steps that can be taken to improve the effectiveness of performance appraisal practices in diversity, such as ensuring multicultural employees on panels that evaluate, select and promote, and using appraisal techniques that focus on appraising the individuals' performance despite their differences. To ensure success, some researchers argue that it is essential that these appraisal techniques are transparent to employees. ${ }^{114}$ These results thus affirm that the B\&B establishments under study were able to differentiate employee performance from ethnicity and non-performancerelated attributes as recommended by Dipboye. ${ }^{115}$

Contrastingly, however, the research finding indicates that employees in the hospitality sector are sometimes faced with challenges of managers who conduct appraisals showing discrimination in one way or the other. ${ }^{116}$ This was corroborated by previous research which reported that adapting performance appraisal techniques to cater for diverse employees may be a challenge and difficult for managers, and, if not handled appropriately, may have a detrimental effect on organisational production. ${ }^{117}$
The results on reward and compensation indicate that employees regard fairness in compensation as good despite their differences. The results contradict the claim that amongst the multitude of challenges related to gender diversity, the most prevalent issue is the equity earnings gap between the gender groups. ${ }^{114}$ Similarly, recent findings indicated that pay inequality, especially gender income inequality, remains a significant issue in diversity management. ${ }^{118}$ Idowu $^{52}$ supported the current findings by stating that managers who implement a performance-based pay system ensure that there is equal pay for equal job to avoid unexplained difference, which according to some researchers may result in loss of motivation and lower job satisfaction. ${ }^{119}$ The idea that performance-based systems which do not rely on individual differences can help to reduce wage disparities for diverse employees is supported by the notion that varieties in pay should not be arbitrarily between the different individuals. ${ }^{120}$

\section{Psychological capital}

With regard to hope as a PsyCap dimension, the results indicate that most of the employees had high hope of their future endeavours as employees. These results are supported by the argument that individuals are motivated to achieve goals through their sense of work. ${ }^{121}$ This fosters internal determination and willpower to invest the energy necessary for achieving the desired goals, with hopeful individuals being more motivated by the desire to develop ways to get things that they want. This means that when B\&B employees continue to have hope, they might be able to identify, clarify and pursue ways to succeed, despite external challenges such as competition in the sector. This in turn allows them to generate multiple pathways to continuously envision goal attainment and success as they prepare to create alternative routes in the face of obstacles blocking their current path. ${ }^{122}$

Respondents in this study showed a high sense of selfefficacy, and these results are supported by a previous study showing that when individuals have a high self-efficacy, they are willing to take on challenging tasks, extend their motivation and effort to achieve goals and to persist in the face of adversity ${ }^{69}$ In the case of $B \& B$, this could mean that despite their inability to be sustainable, their employees are willing to put in more effort. These results thus reaffirm that employees can create their own discrepancies by continuously challenging themselves and setting higher goals. ${ }^{75}$

In terms of resilience, the results indicate that employees also have high resilience attitudes. Numerous researchers have reaffirmed this finding by indicating that because of the nature of the work that the employees in B\&B perform, resiliency comes from the ability to move on after a stressful experience or event, such as personal adversity, conflict and/or failure with a customer. ${ }^{123}$ Ferreira ${ }^{75}$ further suggests that to develop resiliency, employees need to create and prioritise a list of resources, which will enable them to accomplish goals. 
The results on optimism also indicate that employees are highly optimistic. The results confirm that they expect positive and desirable events in the future and tend to attribute their success to themselves, whereas failures are attributed to external factors specific to the situation. ${ }^{75}$ Contrary to this, Tabaziba ${ }^{76}$ indicated that optimism may, however, dysfunction in the workplace as employees who are physically healthy may be pessimistic about their health in the future and neglect their physical and nutritional maintenance at the present. To address these, Ferreira ${ }^{75}$ suggested that managers need to construct a more realistic optimism for employees, which involves an objective assessment of what an individual can accomplish within a specific context (such as B\&B) taking into consideration the available time and resources.

\section{Relationship between diversity management practices and psychological capital}

In terms of the relationship between diversity management practices and PsyCap, the results reveal that when B\&B establishments attract and retain diverse employees, this will positively affect the employees' PsyCap. Employee retention is a critical issue and a challenge for organisations because it costs organisations in terms of recruiting, selecting and training new employees. ${ }^{124}$ However, doing it in a way that shows diversity and does not discriminate (e.g. by using a variety of selection methods and using diverse retention methods) might increase the employees' hope, efficacy, resilience and optimism.

Contrary to the above results, some empirical evidence found that hospitality managers face some of the lowest employee retention rates because of lack of strategies to manage or deal with the nature of diverse employees in the industry. ${ }^{125}$ Usually, this has resulted in staff resignations, loss of customer satisfaction and poor profitability. Similarly, some researchers have found that young hospitality employees are making themselves available to replace the ageing workforce in the industry; however, when the younger workers experience constriction of diversity (which can be viewed as stifling their hope and optimism), they leave. ${ }^{126}$ When this happens, valuable knowledge is lost to the industry. ${ }^{127}$

A research conducted in China amongst Chinese restaurants indicated that having clear career paths or promotion routes that are universally recognised by employees make the employees feel hopeful, thus showing positive organisational behaviours. ${ }^{128}$ In concurrence, some researchers posit that recognising the efforts and input of employees, providing opportunities for employee participation in the management and empowering and delegating challenging tasks to employees are some of the diverse techniques used to eliminate low employee retention rates. ${ }^{124}$ Empirical evidence has shown that such retention strategies have the potential to enhance employees' optimism. ${ }^{125}$

The results showing the correlation between hope and performance appraisal affirm previous findings which indicate that the use of performance appraisals in organisations contributes positively to employee motivation..$^{52}$ Similarly, the findings of other researchers demonstrate that performance appraisal systems strongly affect employees' willingness to work and commit to their jobs or the organisation itself. ${ }^{129}$ In addition, it has long been confirmed that when performance appraisal is implemented fairly, employees become satisfied and it reflects on their work output and performance. ${ }^{130}$ These studies suggest that when performance appraisal is fair and precise, employees will be hopeful and motivated to put more effort to achieve positive goals. Eyoun et al. suggested that the implementation of performance appraisal shapes the personal goals of employees and gives them hope. ${ }^{131}$ In concurrence, research findings note that for an organisation to obtain employee commitment, it should ensure that performance appraisal is well understood, fair and clearly communicated to employees. ${ }^{132}$ This means that a well-communicated performance appraisal process could trigger high levels of commitment and hope for a better future in the organisation for the employees. Levan ${ }^{133}$ summarised that employees' commitment and hope are affected by the organisation's ability to create and implement fair performance appraisals.

The results also show that the diversity management practices variable with the least effect on PsyCap is training and development $(0.167 \leq$ correlation $\leq 0.242)$. These results are in contrast with the research findings, which revealed that hospitality managers reacted most positively when asked whether diversity training made them better managers and least positively when asked whether their own job performance improved after diversity training. ${ }^{111}$ In the present study, the results could therefore mean that, although $\mathrm{B} \& \mathrm{Bs}$ offer diversity training for employees, it is more beneficial for the establishment or organisation than for employees' personal growth and well-being.

In concurrence with the above assumption, researchers argue that even though properly designed diversity training may influence employee attitude, there is little evidence that it changes employee behaviour. ${ }^{40}$ In contrast, other findings maintain that through diversity training, it is likely that employees will benefit from a range of psychological resources that will allow them to take a positive perspective about their new environment and safeguard them against setbacks (resilience).${ }^{90}$ Similarly, recent studies have claimed that PsyCap may positively relate to employee motivation in a training and development context ${ }^{134}$, whilst other research findings concurred that diversity training is also shown to be positively related to employees' stated levels of difficulty and magnitude in coping with diversity initiatives - which could be construed as related to a sense of hope. ${ }^{135}$

The diversity management practice pertaining to reward and compensation has the highest effect on PsyCap variables, with ranges of correlations higher than the other four diversity management practices $(0.351 \leq$ correlation $\leq 0.482)$, with performance appraisal and employee attraction and 
retention following, then employee selection methods, and training and development with the lowest effect size. These results are supported by the research study conducted by Mabaso ${ }^{59}$, which reported that rewards and compensation play a significant role in motivating employees whilst ensuring a high level of performance and work stability. At the same time, previous findings confirmed that motivated employees have resilience and tend to develop high selfefficacy for themselves. ${ }^{136}$ In concurrence, recent research notes that when employees are provided with higher levels of rewards, they tend to put more effort into their work, which might result in high levels of optimism. ${ }^{137}$ However, previous research had claimed that if employees are not satisfied with the rewards and compensation put in place, it will result in lower levels of optimism. ${ }^{138}$ Furthermore, it has been found that when employees are satisfied financially and psychologically, they can perform their work successfully and have hope of growing in their career. ${ }^{139}$ Contrary to the current result, some findings also revealed that there is a negative relationship between rewards and employees' selfefficacy. ${ }^{140}$ This was, however, challenged by recent research findings that showed that employees' self-efficacy is positively influenced by fair and equal rewards. ${ }^{141}$

\section{Practical implications}

In terms of employees' knowledge and understanding of diversity, the study results supported the argument that because of the nature of hospitality industry, diversity is an essential factor that managers and employees should understand. Thus, for B\&Bs to have a sustainable future, they should continue learning about and understand diversity valuing cultural differences and effectively managing their diverse workforce. Such an approach can be complemented by continuously implementing diversity management practices in their human resource functions as well as providing adequate training and development opportunities that can help to eliminate group differences in career outcomes and generate respect for individual differences to retain diverse employees.

Bed and breakfast establishments also need to continue embracing and investing more in their human resource functions, in different ways, to develop and build employees' PsyCap. Alternative strategies such as coaching to make their employees understand their psychological strengths can be utilised to promote employees' psychological states.

It is also recommended that B\&Bs correctly implement fair diversity management practices because this might motivate and develop employees positively, as well as contribute to increased productivity, at the same time positively influencing employees' PsyCap.

\section{Limitations and recommendations}

It is important that the readers of the study note that not much conclusive research has been conducted in the field of both diversity management and PsyCap issues in the hospitality sector. The results of this study should not be generalised to other settings. The author, therefore, advises that apart from the owners or managers of the B\&Bs who contributed to the research findings of this study, others should use the results as just one available option or background for future studies.

Furthermore, it should be noted that B\&Bs that are operated by owners were not considered to avoid biased responses; some B\&Bs meeting the selection criteria blatantly refused to participate. With the remaining and willing B\&Bs, there was a challenge with their availability. Some indicated that they were very busy and promised to participate when and if they can; however, after numerous follow-ups, a few participants eventually refused to participate.

Despite the above limitations, the study holds important recommendations that wish to promote sustainability within the B\&Bs. The sample size that was used in this study is too small and is not a reflection of all the South African B\&B establishments. Therefore, a research with a larger sample size should be conducted in future, covering other areas in the country at large. In addition, future research could conduct and investigate further on the relationship between diversity management practices and PsyCap of employees by incorporating the views of the employers. Furthermore, future research could use qualitative research (interviews) to corroborate data.

\section{Conclusion}

This study contributes to the limited research regarding diversity management practices and PsyCap, specifically within the B\&B establishments. The study found that correct and implemented diversity management practices have a positive influence on employees' PsyCap. From a practical perspective, B\&Bs should consider implementing fair human resource management practices to ensure motivated employees. By doing so, B\&Bs are likely to promote high productivity, performance and sustainability for growth and survival.

\section{Acknowledgements}

The authors would like to thank all the students who participated in the study as well as the institution that granted permission to conduct the study.

\section{Competing interests}

The authors declare that no competing interest exists.

\section{Authors' contributions}

L.P.S. conceptualised the study and focused on literature and data collection. C.C. helped in the write-up and language editing and final presentation of the article.

\section{Funding information}

This research received no grant from any funding agency in the public, commercial or not-for-profit sectors. 


\section{Data availability statement}

Data sharing is applicable to this article. New data were created and analysed and, therefore, can be shared upon reasonable request to the author.

\section{Disclaimer}

The views and opinions expressed in this article are those of the authors and do not necessarily reflect the official policy or positions of any affiliated agency of the authors.

\section{References}

1. South Africa-Republic of Food Service-Hotel restaurant institutional South Africa HRI Sector Report. USDA Foreign Agricultural Services Gain Report. Pretoria: U.S Embassy in South Africa; 2014.

2. Du Plessis AJ, Douangphichit N, Dodd P. HRM in relation to employee motivation and job performance in the hospitality industry. Paper presented at: IBC (Ed.), 9th International Business Conference (IBC); 2015 Dec 02-05; Auckland: Unitec Institute of Technology Research Bank; 2015. p. 55-64.

3. Rogerson CM, Rogerson, JM. City tourism in South Africa: Diversity and change. Tour Rev Int. 2017;2(19):193-211.

4. Statistics South Africa. Tourism jobs grow despite sluggish economy. Pretoria: Department of Statistics, Republic of South Africa; 2018.

5. Makumbirofa S. Forecasting demand for qualified labour in the South African hotel industry. J Econ Fin Sci. 2018;11(1):1-11.

6. Sigauke J, Erdis C. The role of the E-Marketplace as a marketing channel for bed and breakfast enterprises in South Africa. Afr J Hosp Tour Leis [serial online]. 2018 [cited 2018 Feb 3];7(3):1-19. Available from: https://www.ajhtl.com/

7. Republic of South Africa. Local Government Municipal Systems Act (Act 32 of 2000). Notice in terms of Section 14(2)(a)(i) of The Local Government: Municipal
Systems Act, 2000: Publication: Standard Bed and Breakfast Guest House By-Law. No 79. Bloemfontein: Free State Provincial Gazette; 2011.

8. Republic of South Africa. Review of South African Tourism: Report of the Expert Panel to Minister Hanekom, June 2015. Pretoria: SA Tourism Review; 2015.

9. Monyaki $L$. The impact of selected individual and organisational factors on intention to quit among employees: $A$ case of bed and breakfast (B\&B) establishments in Thabo Mofutsanyane District, Free State [unpublished dissertation]. Bloemfontein: Central University of Technology, Free State; 2016.

10. Vallabh D, Kutsi H. Perceived economic impacts of the National Arts Festival on Bed and Breakfast establishments: A case study of Grahamstown, Joza Location. Afr J of Hosp Tour Leis [serial online]. 2018 [cited 2019 Mar 2];7(4):1-8. Available from: https://www.ajhtl.com/

11. Lebambo M, Shambare R. Entrepreneurship policies versus practice: A great divide for tourism establishments in rural South Africa. Proceedings of the 39th Global Business and Technology Association Conference; 2017 July 11-15; Vienna, Austria. New York, NY: Global Business and Technology Association; 2017.

12. Chili NS, Mabaso SL. The challenges of developing small tourism enterprises in townships: Case of Umlazi, South Africa. Prob Pers Manag [serial online]. 2016 [cited 2019 Apr 20];14(1):201-204. Available from: https://www.researchgate. net/publication/301678634; https://doi.org/10.21511/ppm.14(1-1).2016.08

13. Ali $M$, French E. Age diversity management and organisational outcomes: The role of diversity perspectives. Hum Res Manag J [serial online]. 2019 [cited 2019 Aug 10];29(2):287-307. Available from: https://onlinelibrary.wiley.com/doi/abs /10.1111/1748-8583.12225

14. Backhaus N. Managing diversity: The Government of a Malaysian Hawker Place. Malay Manah J [serial online]. 2019 [cited 2019 Oct 3];19(5):65-76. Available from: https://www.researchgate.net/publication/305619802

15. Elkhwesky Z, Salem IE, Barakat M. Diversity management in hotels: The moderating role of empowerment and capability development. J Hosp Tour Ins [serial online]. 2019 [cited 2019];2(2):166-185. Available from: https://www. emerald.com/insight/content/doi/10.1108/JHTI-09-2018-0058/full/html; https:// doi.org/10.1108/JHTI-09-2018-0058

16. Manoharan A, Sardeshmukh SR. Gross MJ. Informal diversity management practices and their effectiveness: In the context of ethnically diverse employees in hotels. Int J Hosp Manag [serial online]. 2019 [cited 2019 Oct 12]:82:181-190. Available from: https://www.sciencedirect.com/science/article/abs/pii/ S0278431918308776; https://doi.org/10.1016/j.ijhm.2019.05.003

17. Ng ES, Seara GJ. Walking the talk on diversity: CEO beliefs, moral values, and the implementation of workplace diversity practices. J Bus Ethics [serial online]. 2020 [cited 2020 Jul 18];164:437-450. Available from: https://www.researchgate.net/ [cited $2020 \mathrm{Jul}$ 18];164:437-450. Available from: https://www.research
publication/328797237; https://doi.org/10.1007/s10551-018-4051-7

18. Safavi HP, Bouzari M. The association of psychological capital, career adaptability and career competency among hotel frontline employees. Tour Manag Pers [serial online]. 2019 [cited 2020 Jul 19];30:65-74. Available from: https://www. online]. 2019 [cited 2020 Jul 19];30:65-74. Available from: https://www.
researchgate.net/publication/332123040; https://doi.org/10.1016/j.tmp.2019. research
02.001
19. De Hoe R, Janssen F. Developing psychological capital to learn and bounce back from entrepreneurial failure [unpublished dissertation]. Leuven: Universite Catholique de Louvain; 2014.

20. Lebambo M. The role of entrepreneurial policies in developing rural tourism entrepreneurship in South Africa. Afr J Hosp Tour Leis [serial online]. 2019 [cited 2017 Feb 3];8(3):1-21. Available from: http://hdl.handle.net/10210/294624//:www. ajhtl.com

21. Chipunza LT. Driving innovation in small accommodation businesses: A comparative study of Zimbabwe and South Africa [unpublished dissertation]. Bloemfontein: Central University of Technology, Free State; 2014.

22. Ohunakin F, Adeniji AA, Ogunnaike OO, Igbadume F, Akintayo DI. The effects of diversity management and inclusion on organisational outcomes: A case of multinational corporation. Vers: teor ir prak [serial online]. 2019 [cited $2020 \mathrm{Jul}$ multinational corporation. Vers: teor ir prak [serial online]. 2019 [cited $2020 \mathrm{Jul}$
16];10(1):93-102. Available from: https://www.researchgate.net/publication/ 331557670; https://doi.org/10.3846/btp.2019.09

23. Gala CA. The extent of knowledge about the hospitality industry among life orientation teachers and learners in previously disadvantaged black schools in Cape Town, South Africa [unpublished dissertation]. Cape Town: Cape Peninsula University of Technology, Cape Town: 2017.

24. Van der Schyff T, Meyer D, Ferreira L. An analysis of impact of the tourism sector as a viable response to South Africa's growth and development challenges. J Int Stud [serial online]. 2019 [cited 2020 Jul 23];16(1):168-183. Available from: https:// www.jois.eu/?497,en; https://doi.org/10.14254/2071-8330.2019/12-1/11

25. PricewaterhouseCoopers (PWC). Building thrust through assurance. Transparency report for the year ended 20 June 2018 [homepage on the Internet] 2018.[cited 2019 Oct 23]; PWC Publication. Available from: https://www.pwc.co.za/en/ assets/pdf/transparancy-report-2018.pdf

26. Visser G, Inge E, Miller M. Airbnb: The emergence of a new accommodation type in Cape Town, South Africa. Tour Rev Int [serial online]. 2017 [cited 2019 Nov 3];21(2):151-168. Available from: https://www.ingentaconnect.com/contentone/ $\mathrm{cog} /$ tri/2017/00000021/00000002/art00005?crawler=true\&mimetype=applicati on/pdf; https://doi.org/10.3727/154427217X14912408849458

27. Tichaawa T, Mhlanga O. Guest experiences of service quality in bed and breakfast establishments in East London, South Africa. J Hum Ecol [serial online]. 2015 [cited 2017 Jun 23];50(2):93-101. Available from: https://www.researchgate.net/ publication/282862550; https://doi.org/10.1080/09709274.2015.11906863

28. Donaldson R. Small town tourism in South Africa. Cape Town: Springer; 2018.

29. Hlanyane TM, Acheampong KO. Tourism entrepreneurship: The contours of challenges faced by female-owned BnBs and Guesthouses in Mthatha, South Africa. Afr J Hosp Tour Leis [serial online]. 2017 [cited 2019 Sep 17];6(4):1-17. Available from: https://www.researchgate.net/publication/32192039; http//:www.ajhtl.com

30. Talabi J. The role of marketing in hotel industry. Case of six successful hotel units in Abuja and Jukobstad [unpublished dissertation]. Abuja: Centria University of Applied Sciences: 2015

31. Hong $Y$, Cai G, Mo Z, et al. The Impact of COVID-19 on Tourist satisfaction with B\&B in Zhejiang, China: An importance-performance analysis. Int J Env Res Pub Health [serial online]. 2020 [cited 2020 Jul 24]:17(10):2-20. Available from: https://www. [serial online]. 2020 [cited $2020 \mathrm{Jul}$ 24];17(10):2-20. Available from: https://www.
researchgate.net/publication/341645422; https://doi.org/10.3390/ijerph17103747.

32. Sharma S, Sharma R. Culinary skills: The spine of the Indian hospitality industry: Is the available labor being skilled appropriately to be employable? Ww Hosp Tour Them [serial online]. 2019 [cited 2019 Nov 10];11(1):25-36. Available from: https://www.emerald.com/insight/content/doi/10.1108/WHATT-10-2018-0061/ full/html; https://doi.org/10.1108/WHATT-10-2018-0061

33. Victoria J. Exploring entrepreneurial networking in small hospitality businesses in Malaysia [unpublished dissertation]. Minnesota, MN: University of Minnesota; 2018.

34. Sanjeev GM, Birdie AK. The tourism and hospitality industry in India: Emerging issues for the next decade. Ww Hosp Tour Them [serial online]. 2019 [cited 2019 Sep 2];11(4):355-361. Available from: https://www.emerald.com/insight/ content/doi/10.1108/WHATT-05-2019-0030/full/html; https://doi.org/10.1108/ WHATT-05-2019-0030.

35. Aybas M, Acar AC. The effect of human resource management practices on employees' work engagement and the mediating and moderating role of positive psychological capital. Int Rev Manang. 2017;7(1):363-372.

36. Velten L, Lashley $C$. The meaning of cultural diversity among staff as it pertains to employee motivation. J Res Hosp Manag [serial online]. 2018 [cited 2019 Jun 25];7(2):105-113. Available from: https://www.tandfonline.com/doi/abs/10.108 $0 / 22243534.2017 .1444718$

37. Bedi P, Lakra P, Gupta E. Workforce diversity management: Biggest challenge or opportunity for 21st century organisations. J Bus Manag [serial online]. 2014 [cited 2018 Apr 4];16(4):102-107. Available from: https://www.semanticscholar. org/paper/; https://doi.org/10.9790/487X-1643102107

38. Bogers M, Foss NJ, Lyngsie J. The 'human side' of open innovation: The role of employee diversity in firm-level openness. Res Pol [serial online]. 2017 [cited 2019 Oct 1];47(1):218-231. Available from: https://www.sciencedirect.com/science/ article/abs/pii/S0048733317301828; https://doi.org/10.1016/j.respol.2017.10.012

39. Wambui TW, Wangombe JG, Muthura MW, Kamau AW, Jackson SM. Managing workplace diversity: A Kenyan perspective. Int J Bus Soc Sci [serial online]. 2013 [cited 2019 May 20];4(16):199-218. Available from: https://www.researchgate. net/publication/303893112

40. Kalargyrou V, Costen W. Diversity management research in hospitality and tourism: Past, present and future. Int J Contemp Hosp Manag [serial online]. 2017 [cited 2016 Jun 30];29(1):68-114. Available from: https://www.researchgate.net/ publication/312667981; https://doi.org/10.1108/IJCHM-09-2015-0470 
41. Dennisen M, Benschop Y, Van den Brink M. Rethinking diversity management: An intersectional analysis of diversity networks. Org Stud. 2020;41(2):219-240.

42. Chung KL, D’Annunzio-Green N. Talent management practices in small- and medium-sized enterprises in the hospitality sector: An entrepreneurial ownermanager perspective. Ww Hosp Tour Them [serial online]. 2018 [cited Nov 2019];10(1):101-116. Available from: https://www.researchgate

43. Chytiri A, Filippaios F, Chytiris L. Hotel recruitment and selection practices: The case of the Greek Hotel Industry. Int J Org Lead [serial online]. 2018 [cited 2019 Sep 12];7:324-339. Available from: https://www.researchgate.net/ [cited 2019 Sep 12];7:324-339. Available from: https://www.resear
publication/331515774; https://doi.org/10.33844/ijol.2018.60465

44. Yusuf $B$, Kehinde A. Recruitment and selection procedures and their relative effectiveness on employees' performance in the hospitality industry in Ogun State. Int J Gu Cont Acad Res [serial online]. 2017. [cited 2019 Oct 24];2(2):55-62. Available from: https://www.researchgate.net/publication/31904422

45. Nyarko CO. Recruitment and Selection Practices adopted by SMEs in microfinance firms in the Accra Metropolitan area of Ghana. Adv Soc Sci Res J [serial online]. 2016 [cited 2018 Jul 10];3(11):1-23. Available from: https://www.researchgate. net/publication/312239635; https://doi.org/10.14738/assrj.311.1912

46. Ruiz-Jiménez, JM, Del Fuentes-Fuentes M. Management capabilities, innovation, and gender diversity in the top management team: An empirical analysis in technology-based SMEs. BRQ Bus Res Quart [serial online]. 2016 [cited 2017 Feb 20];19(2):107-121. Available from: https://www.econbiz.de/Record/; https://doi. 20];19(2):107-121. Available from:
org/10.1016/j.brq.2015.08.003

47. Padachi K, Bhiwajee, LS. Barriers to employee training in small and medium sized enterprises: Insights and evidences from Mauritius. Eur J Tr Dev [serial online] 2016 [cited 2016 May 10]:40(4):232-247. Available from: https://www.emerald. com/insight/content/doi/10.1108/EJTD-02-2014-0018/full/html; https://doi. com/insight/content/doi/10.1108/E
org/10.1108/EJTD-02-2014-0018

48. Gumede M. The impact of cultural diversity on organisational performance and success [unpublished dissertation]. Durban: University of KwaZulu-Natal; 2016.

49. Tuul O, Bing S. Employee training in small and medium-sized enterprises in Mongolia. Proc Mong Acad Sc [serial online]. 2019 [cited 2018 Aug 4];59(1): 75-84. Available from: https://www.mongoliajol.info/index.php/PMAS/article/ view/1140; https://doi.org/10.5564/pmas.v59i1.1140

50. Okello ES. Relationship between diversity and organisational performance of State Corporations in the coastal region of Kenya [unpublished]. Abuja: University of Nairobi; 2015.

51. Alghazo AM, Shaiban HM. The effects of workforce diversity on employee performance at an Oil and Gas company. Am J Bus Soc. 2016;1(3):148-153.

52. Idowu A. Effectiveness of Performance appraisal system and its effect on employee motivation. N J Bus Econ. 2017;3(5):15-39.

53. Brawley AM. Performance management in family microbusinesses [unpublished dissertation]. Clemson, SC: Clemson University; 2016

54. Chepngetich P. Effect of financial literacy and performance SMEs. Evidence from Kenya (2016). Am Res J [serial online]. 2016 [cited 2017 Oct 5];5(11):26-35. Available from: SSRN: https://ssrn.com/abstract=2882997

55. Adeoye AO. Compensation management and employees' motivation in the insurance sector: Evidence from Nigeria. Fac Un Econ Org [serial online]. 2019
[cited 2020 Jul 21];17(1):31-47. Available from: https://www.researchgate.net/ publication/333923661; https://doi.org/10.22190/FUEO1901031A

56. Reddy MVB, Ra PB, Venugopal I. The importance of compensation management for improving the performance of sales force. Int J Res. 2019;8(2) 1170-1177.

57. Todorović S, Radišić M, Takači A, Borocki J, Kliestikova J. Impact of internal additional compensations policy on revenues in cross-sectoral SME environment. Eur J Int Manag [serial online]. 2019 [cited 2019 Sep 4];14(6):843-853. Available from: https://www.researchgate.net/publication/336388060; https://doi.org/10.1504/ https://www.research

58. Veldsman DM. Perceptions of diversity management in a public sector organisation/government institution within the Western Cape [unpublished dissertation]. Cape Town: University of Western Cape; 2013.

59. Mabaso CM. The influence of rewards on job satisfaction and organisational commitment among academic staff at selected Universities of Technology in South Africa [unpublished dissertation]. Durban: Durban University of Technology; 2017.

60. Deng YT, Lee $H$. Exploring the dimensions of bed and breakfast (B\&B) visitors' experiences. Int J Tour Sci. 2019;19(3):166-180.

61. Zhang GH, Meng Y. The study of bed and breakfast tourism development. Res Dev Mar. 2017;33(4):503-507.

62. Hajjar L, Hugonet C. Diversity within small and medium-sized enterprises- best practices and approaches for moving ahead. Luxembourg: European Union; 2015.

63. Chiu CN. Taiwanese bed and breakfast business performance: A geographic region perspective. Growth and Change. J Urb Reg Pol [serial online]. 2019 [cited 2020 Jul 19];50(3):1102-114. Available from: https://onlinelibrary.wiley.com/doi/ abs/10.1111/grow.12313; https://doi.org/10.1111/grow.12313

64. Boudreaux CJ. Ethnic diversity and small business venturing. Small Bus Econ. 2020;54:25-41.

65. Verrynne ML, Wiliams AM, Ritchie BW, Gronum S, Betts KS. Innovation diversity and uncertainty in small and medium sized tourism firms. Tour Manag [serial online]. 2019 [cited 2020 Jul 23];72:257-269. Available from: https://www. sciencedirect.com/science/article/abs/pii/S0261517718303005; https://doi. org/10.1016/j.tourman.2018.11.019

66. Aziz AY, Awang KW, Zaiton S. Challenges faced by micro, small, and medium lodgings in Kelantan, Malaysia. Int J Econ Manag. 2012;6(1):167-190.
67. Georgiadou A, Gonzalez-Perez MA, Olivas-LujÃin MR. Diversity within diversity management: Where we are, where we should go, and how we are getting there. Adv Ser Manag [serial online]. 2019 [cited 2018 Aug 12];21:1-20. Available from: Attps://www.researchgate.net/publication/332022635; https://doi.org/10.1108/ https://www.researchgate.net/p

68. Carmona-Halty M, Salanova M, Gumbau SL, Schauflei WB. How psychological capital mediates between study-related positive emotions and academic performance. J Happ Stud [serial online]. 2019 [cited 2018 Oct 3];20:605-617. Available from: https://www.researchgate.net/publication/322582133; https:// Available from: https://www.research

69. Dawkins SL. New directions in psychological capital research: A critical analysis and theoretical and empirical extensions to individual-and team-level measurement [unpublished dissertation]. Hobart: University of Tasmania; 2014.

70. Tsaur SH, Hsu SF, Lin H. Workplace fun and work engagement in tourism and hospitality: The role of psychological capital. Int J Hosp Manag. 2019;81:131-140.

71. Herbert M An exploration of the relationships between psychological capital (hope, optimism, self-efficacy, resilience), occupational stress, burnout and employee engagement [unpublished dissertation]. Cape Town: Stellenbosch University; 2011.

72. Luthans F, Youssef CM. Emerging positive organisational behaviour. J Manag. 2007;33(3):321-349.

73. Saraswati K. Work engagement: The impact of psychological capital and organizational justice and its Influence on turnover Intention. J Manag Market Rev. 2019;4(1):86-91.

74. Choi J. The effects of autonomous work environment and positive psychological capital on self-directed employee behaviour: Evidence from Korea [unpublished dissertation]. Urbana-Champaign: University of Illinois; 2014

75. Ferreira T. The relationship between psychological capital and work engagement amongst correctional officers at a correctional facility in the Western Cape [unpublished dissertation]. Cape Town: University of Western Cape; 2015.

76. Tabaziba KR. Psychological capital and work engagement: An investigation into the mediating effect of mindfulness [unpublished dissertation]. Cape Town: University of Cape Town; 2015.

77. Na Ayutthaya JS, Tuntivivat S, Prasertsin U. The effect of positive psychological capital and organisational climate on service quality: The mediation role of work engagement of hotel service employees in Ratchaburi Province. J Adm Bus Stud. 2016;2(4):167-176.

78. Bogler R, Somech A. Psychological capital, team resources and organizational citizenship behaviour. J Psychol Inter App. 2019;153(8):784-802.

79. Hoang G, Wilson-Evered E, Lockstone-Binney L. Leading innovation among tourism small and medium enterprises: Examining the mediating role of climate for innovation. Lead Org Dev J [serial online]. 2019 [cited 2019 May 14];40(5):647-666. Available from: https://www.emerald.com/insight/content/ 14];40(5):647-666. Available from: https://W
doi/10.1108/LODJ-08-2018-0287/full/html

80. Bayramoğlu G, Sahin M. Positive psychological capacity and its impacts on success. J Adv Manag Sci. 2015;3(2):154-157.

81. Luthans KW, Luthans BC, Chaffin TD. Refining grit in academic performance: The mediational role of psychological capital. J Manag Ed [serial online]. 2018 [cited 2019 Nov 13];43(1):35-61. Available from: https://journals.sagepub.com/ doi/10.1177/1052562918804282; https://doi.org/10.1177/1052562918804282

82. Bockorny K, Yousef-Morgan CM. Entrepreneurs' courage, psychological capital, and life satisfaction. Front Psychol [serial online]. 2019 [cited 20120 Ju fpsyg.2019.00789/full; https://doi.org/10.3389/fpsyg

83. Baron R, Franklin R, Hmieleski K. Why entrepreneurs often experience low, not high, levels of stress: The joint effects of selection and psychological capital. J Manag. 2016;42;742-768. https://doi.org/10.1177/0149206313495411

84. Solomon S. The relationship between psychological capital and employee wellness in organisations in the manufacturing industry in the Western Cape [unpublished dissertation]. Cape Town: University of the Western Cape; 2014.

85. Dhir R, Sharma V. Exploring dimensions of psychological capital through grounded theory investigation. Int J Ind Cult Bus Manag [serial online]. 2020 [cited 2020 Jul 21];20(1). Available from: https://ideas.repec.org/a/ids/ijicbm/v20y2020i1p109-132. html; https://doi.org/10.1504/IJICBM.2020.105556

86. Lee C, Chu K. Understanding the effect of positive psychological capital on hospitality interns' creativity for role performance. Int J Org Inn. 2016;8(4):213-222.

87. Ashikali T, Groeneveld S, Kuipers B. The role of inclusive leadership in supporting an inclusive climate in diverse public sector teams. Rev Pub Pers Adm [serial online]. 2020 [cited 2020 Jul 24];1-23. Available from: https://journals.sagepub. com/doi/pdf/10.1177/0734371X19899722

88. Chapman G, Radford K. Positive psychological capital and employee retention: A new perspective for the ageing workforce [unpublished dissertation]. Brisbane: Griffith University; 2015.

89. Fang S, Prayan G, Ozanne LK, De Vries H. Psychological capital, coping mechanisms and organizational resilience: Insights from the 2016 Kaikoura earthquake. N Zeal Tour Manag Pers. 2020;34:1-12.

90. Reichard RJ, Dollwet M, Louw-Potgieter J. Development of cross-cultura psychological capital and its relationship with cultural intelligence and ethnocentrism. J Lead Org Stud. 2014;21(2):150-164.

91. Mousa M, Massoud HK, Ayoubi RM. Gender, diversity management perceptions, workplace happiness and organisational citizenship behaviour. Empl Relat [serial online]. 2020 [cited 2020 Jul 20]; Available from: https://www.emerald.com/ online]. 2020 [cited 2020 Jul 20]; Available from: https://www.emerald.com/
insight/content/doi/10.1108/ER-10-2019-0385/full/html; https://doi.org/10.1108/ insight/content/do-2019-0385 
92. Engelhard F, Garg R. The influence of intra-cultural diversity on self-efficacy beliefs: Evidence from India. Int J Ind Cult Bus Manag [serial online]. 2018 [cited 2017 May 12];16(2):131-155. Available from:https://ideas.repec.org/ [cited 2017 May 12];16(2):131-155. Available from:https://ideas.repec.org/ a/ids/ijicbm/ 2018.090086

93. Seligman M. Flourish: A visionary new understanding of happiness and wellbeing. New York, NY: Free Press; 2011.

94. Kern ML Waters L, Adler A, White MA. Assessing employee wellbeing in schools sing a multifaceted approach: Associations with physical health life satisfaction, and professional thriving. Psychology [serial online]. 2014 [cited 2019 Nov 12];5(6):500-513. Available from: https://www.researchgate.net/ publication/272876705; https://doi.org/10.4236/psych.2014.56060

95. D'raven LL, Pasha-Zaidi N. Using the PERMA Model in the United Arab Emirates. Soc Ind Res. 2016;125:905-933

96. Ziyae B, Mobaraki MH, Mozhgan S. The effect of psychological capital on innovation in information technology. J Glob Entr Res. 2015;5(8):1-12.

97. Ghasemi A, Zahediasl S. Normality tests for statistical analysis: A guide for nonstatisticians. Int J Endocrinol Metab [serial online]. 2012 [cited 2020 Ju 21];10(2):486-489. Available from: https://www.ncbi.nlm.nih.gov/pmc/articles/ PMC3693611/; https://doi.org/10.5812/ijem.3505

98. Das AHM, Imon R. A brief review of tests for normality. Am J Theor App Stat [serial online]. 2016 [cited 2019 Sep 3];5(1):5-12. Available from: http://www.sciencepublishinggroup.com/; https://doi.org/10.11648/j.ajtas. 20160501.12

99. Treuren GJM, Manoharan A, Vishnu V. The hospitality sector as an employer of skill discounted migrants. Evidence from Australia. J Pol Res Tour Leis Ev [serial online]. 2019 [cited 2020 Jul 14];12(3):234-246. Available from: https://www. online]. 2019 [cited 2020 Jul 14];12(3):234-246. Available from: https://www.
tandfonline.com/doi/abs/10.1080/19407963.2019.1655859?journalCode=rp tandfonline.com/doi/abs/10.1080/19407963.2019.165

100. Daniels J. Employee perceptions towards diversity management in a glass manufacturing company in the Western Cape [unpublished dissertation]. Cape Town: University of Western Cape; 2012.

101. Sakdiyakorn M, Wattanacharoensil W. Generational diversity in the workplace: A systematic review in the hospitality context. Cor Hosp Quart. 2018;59(2): 135-159.

102. Manoharana A, Singal M. A systematic literature review of research on diversity and diversity management in the hospitality literature. Int J Hosp Manag. 2017;66(9):67-91

103. Gut A, Wilczewski M, Gorbaniuk O. Cultural differences, stereotypes and communication needs in intercultural communication in a global multicultura environment. The employees' perspective. J Int Comm [serial online]. 2017 [cited 2019 Nov 19];43. Available from: http://immi.se/intercultural

104. Badran N, Khalifa G. Diversity management: Is it an important issue in hote industry in Egypt? Int J Herit Tour Hosp [serial online]. 2016 [cited 2020 Ju 26];7(2):275-284. Available from: https://www.researchgate.net/publication/ 326723884

105. Malik R, Madappa T, Chitranshi J. Diversity management in tourism and hospitality: An exploratory study. Foresight. 2017;19(3):323-336.

106. Singh R, Rigsby J, Ramgulam N. A study of Small and Medium-Sized Enterprises (SMEs) in Trinidad: Formal human resource management practices and the performance of SMEs. J East Car Stud. 2017;42(2):53-81.

107. Babalola SS, Marques L. Integrated approach to workplace diversity through human resource management. J Soc Dev Sci. 2013;4(9):435-445.

108. Zolzaya E, Hong ZX. The research of Mongolian SMEs human resource recruitment and selection in some problem. Proc Mong Acad Sci [serial online]. 2019 [cited 2018 Aug 4];58(1):75-84. Available from: https://www.mongoliajol. info/index.php/PMAS/article/view/1140; https://doi.org/10.5564/pmas. v59i1.1140

109. Sakdiyakorn M, Wattanacharoensil W. Generational diversity in the workplace: A systematic review in the hospitality context. Corn Hosp Quart [serial online] 2017 [cited 2019 Feb 23];59(2):1-35. Available from: https://journals.sagepub. com/doi/abs/10.1177/1938965517730312

110. Rabie C, Cant MC, Wiid JA. Training and Development in SMEs: South Africa's key to survival and success? J App Bus Res. 2016;32(4):1009-1024.

111. Reynolds D, Rahman I, Bradetich S. Hotel managers' perceptions of the value of diversity training: An empirical investigation. Int J Cont Hosp Manag. 2014;6(3):426-446.

112. Pauli U. Training professionalisation and SME performance. Hum Res Dev Int 2020;23(2):168-187

113. Zakaria N, Fauzi WIM, Abdullah AC, Yusoff RZ. The Link between HRM practices and performance in Malaysian SMEs. Int. J Sup Chain Manag. 2018;7(6):118-126.

114. Majid J. Effectiveness of performance appraisal methods - An empirical study of the Telecommunication Sector. Int J Trend Res Dev. 2016;3(3):10-17.

115. Dipboye RL. Criterion development, performance appraisal, and feedback. In: The Emerald review of industrial and organizational psychology [homepage on the Internet]. 2018 [cited 2018 Jun 19]; p. 535-579. Available from: https:// www.researchgate.net/publication/327028678_11; https://doi.org/10.1108/ 978-1-78743-785-220181015
116. Sharma A, Nissar T. Managing diversity and equality in the workplace. Cog Bus Manag [serial online]. 2016 [cited 2019 Aug 2];3(1):1-14. Available from: https://www.tandfonline.com/doi/pdf/10.1080/23311975.2016.1212682?nee dAccess=true; https://doi.org/10.1080/23311975.2016.1212682

117. O'Donovan D, Linehan M. The impact of inclusion on performance: Perceptions of nurses in the Irish Healthcare Sector. Paper presented at: Irish Academy of Management; 2014 Sep 10-14; Limerick: University of Limerick; 2014.

118. Owen AL, Temesvary J. CEO compensation, pay inequality, and the gender diversity of bank board of directors. Fin Res Lett. 2019;30:276-279.

119. Van der berg-Ros A. An assessment on managing workforce diversity in public sector organisations: the case of the department of Local Government Western Cape (WC) [unpublished dissertation]. Cape Town: University of Stellenbosch; 2013.

120. Patnaik P, Suar D. Analyses of publications on compensation management from 2004 to 2017. Comp Ben Rev. 2019;51(2):55-76.

121. Saeid M, Homam M. The role of psychological capital components (hope, optimism, resiliency and self-efficacy) and achievement goals orientation in predicting academic procrastination in students. J Cog Str Learn. 2017;5(8):61-78.

122. Bouzari M, Karatepe OM. Test of a mediation model of psychological capital among hotel salespeople. Int J Cont Hosp Manag. 2017;29(8):2178-2197.

123. Edeh FO, Ugwu, JN, Ikpor, IM, Udeze, CG, Ogwu, VO. Workplace democracy and employee resilience in Nigerian hospitality industry. Am J Econ Bus Manag. 2018;2(4):147-162

124. Siddiq A, Ganesha B. A study on employee turnover in hospitality industry in D. L district, Karnataka [unpublished dissertation]. Konaje: Mangalore University; 2017.

125. Scott B, Revis S. Talent management in hospitality: Graduate career success and strategies. Int J Cont Hosp Manag [serial online]. 2008 [cited 2019 Nov 27];20(7):781-791. Available from: https://www.researchgate.net/publication/ 241453168; https://doi.org/10.1108/0959611081089760

126. Mooney S, Ryan I, Harris C. The Intersections of gender with age and ethnicity in hotel careers: Still the same old privileges? Gend Work Org. 2017;24(4): 360-375.

127. Fernandez KM, Worasuwan K. Drivers of hotel employee retention; A comparative study. Un J Manag. 2017;5(11):497-501.

128. Gu B. Effects of psychological capital on employee turnover intentions: A study based on Hai Di Lao Hot Pot. J Glob Tour Res. 2016;1(1):21-28.

129. Kibichii KE, Kiptum KG, Chege K. Effects of performance management process on employee productivity: A survey of commercial banks in Turkana County. J Bus Manag. 2017;18(11):52-64.

130. Asamoah $\mathrm{H}$. The effects of performance appraisal on employee attitude: A case of first allied savings and loans Ltd [unpublished dissertation]. Kumasi: Kwame Nkrumah University of Science and Technology; 2012.

131. Eyoun K, Chen H, Ayoun B, Khliefat A. The relationship between purpose of performance appraisal and psychological contract. Generational differences as a moderator. Int J Hosp Manag. 2020;86:1-8.

132. Kaposambo V. Employee perception of performance appraisal and its relationship with organisational commitment: The case of a meat corporation in Namibia [unpublished dissertation]. Cape Town: University of Cape Town; 2016.

133. Levan B. Examining the relationship between performance appraisal reactions and employee engagement [unpublished dissertation]. Tyler, TX: The University of Texas at Tyler; 2017.

134. Georgiou K, Nikolaou I, Turban, DB. The impact of training intervention developing psychological capital on job search success. J Career Dev [serial developing psychological capital on job search success. Jareer Dev [serial net/publication/333827275; https://doi.org/10.1177/0894845319852425

135. Duchek S, Raetze S, Scheuch I. The role of diversity in organizational resilience: A theoretical framework. Bus Res. 2019. Available from: https://link.springer.com/ content/pdf/10.1007/s40685-019-0084-8.pdf; https://doi.org/10.1007/ s40685-019-0084-8

136. Schwarzer R, Warner LM. Percieved self-efficacy and its relationship to resilience. In: Prince-Embury S, Salofske DH, editors. Resilience in children, adolescents, and adult. New York, NY: Springer-Verlag, 2013; p. 139-150.

137. Victor J, Hoole C. The influence of organisational rewards on workplace trust and work engagement. SA J Hum Res Manag [serial online]. 2017 [cited 2019 Jun 10];15(a853):1-14. Available from: https://sajhrm.co.za/index.php/sajhrm/ article/view/853/120; https://doi.org/10.4102/sajhrm.v15i0.853

138. Shelton SA, Renard M. Correlating nurses' levels of psychological capital with their reward preferences and reward satisfaction. SA J Ind Psychol [serial online]. 2015 [cited 2019 Oct 8];41(1):1-14. Available from: https://sajip.co.za/index. php/sajip/article/view/1271; https://doi.org/10.4102/sajip.v41i1.1271

139. Zaraket WS, Saber F. The impact of financial reward on Job satisfaction and performance: Implications for Blue Collar Employees. China-USA Bus Rev. 2017;16(8):369-378.

140. Tzur KS, Ganzah Y, Pazy A. On the positive and negative effects of self-efficacy on performance: Reward as a moderator. Hum Perform. 2016;29(5):362-377.

141. Park J, Yang, JS. Moderating effects of the timing of reward determination and performance standards between rewards and self-efficacy for sustainable intrinsic motivation. Sustainability. 2019;11(17):1-20. 